\title{
Phylogeny, phylogeography and hybridization of Caucasian barbels of the genus Barbus (Actinopterygii, Cyprinidae)
}

Boris A. Levin ${ }^{1,2 * \#}$, Alexander A. Gandlin ${ }^{1 \#}$, Evgeniy S. Simonov ${ }^{3 \#}$, Marina A. Levina ${ }^{1}$, Anna E. Barmintseva $^{4}$, Bella Japoshvili ${ }^{5}$, Nikolai S. Mugue ${ }^{4}$, Levan Mumladze ${ }^{5}$, Namig J. Mustafayev ${ }^{6}$ Andrey N. Pashkov ${ }^{7}$, Haikaz R. Roubenyan ${ }^{8}$, Maxim I. Shapovalov ${ }^{9}$, Ignacio Doadrio ${ }^{10}$

${ }^{1}$ Papanin Institute of Biology of Inland Waters, Russian Academy of Sciences, 152742 Borok, Yaroslavl Province, Russia

${ }^{2}$ Cherepovets State University, Cherepovets, Russia

${ }^{3}$ Siberian Federal University, Krasnoyarsk, Russia

${ }^{4}$ Russian Federal Research Institute of Fisheries and Oceanography, Moscow, Russia

${ }^{5}$ Institute of Zoology and Institute of Ecology of Ilia State University, Cholokashvili ave. 3/5, 0162, Tbilisi, Georgia

${ }^{6}$ Institute of Zoology, National Academy of Sciences of Azerbaijan, Baku, Azerbaijan

${ }^{7}$ Krasnodar Department, Federal State Budgetary Scientific Institution “Azov Sea Research Fisheries Institute”, Krasnodar, Russia

${ }^{8}$ Scientific Center of Zoology and Hydroecology, National Academy of Sciences of Republic of Armenia, Yerevan, Armenia

${ }^{9}$ Adyghe State University, Maykop, Republic of Adygeya, Russia

${ }^{10}$ Museo Nacional de Ciencias Naturales (CSIC), Madrid, Spain

*Corresponding author: Tel: +7 4854724042 Fax: +7 48547 24042. E-mail: borislyovin@ mail.ru 


\begin{abstract}
The phylogenetic relationships and the phylogeography of seven species of Caucasian barbels of the genus Barbus s. str. were studied based on extended geographic coverage and the use of mtDNA and nDNA markers. Based on the 26 species studied, matrilineal phylogeny of the genus Barbus is composed of two clades: a) West European clade, and b) Central and East European clade. The latter comprises two subclades: b1) Balkanian subclade, and b2) Ponto-Caspian subclade, which includes 11 lineages mainly from Black and Caspian Sea drainages. Caucasian barbels are not monophyletic and are subdivided into two groups. The Black Sea group encompasses species from tributaries of the Black Sea, including the reinstalled B. rionicus, except for B. kubanicus. The Caspian group includes B. ciscaucasicus, B. cyri (with B. goktschaicus, which might be synonymized with B. cyri), B. lacerta from the Tigris-Euphrates basin and B. kubanicus from the Kuban basin. The genetic structure of Black Sea barbels was influenced by glaciation-deglaciation periods accompanied by freshwater phases, periods of migration and the colonization of Black Sea tributaries. Intra- and intergeneric hybridization among Caucasian barbines was revealed for the first time. In the present study, we report the discovery of $B$. escherichii in the Kuban basin, where only B. kubanicus was known to inhabit. Hybrids of these two species were detected based on both mtDNA and nDNA markers. Remarkably, the Kuban population of $B$. escherichii is distant to closely located conspecific populations, and we consider it as a relic. We reveal the intergeneric hybridization between evolutionary tetraploid $(2 \mathrm{n}=100)$ B. goktschaicus and evolutionary hexaploid $(2 \mathrm{n}=150)$ Capoeta sevangi in Lake Sevan.
\end{abstract}

Key words: Cyprinidae, phylogeny, Barbus, taxonomy, Caucasus, hybridization 


\section{Introduction}

Polyploid cyprinids are a large group widely distributed in Eurasia and Africa. The freshwater fishes of the genus Barbus s. str. are of a tetraploid lineage $(2 \mathrm{n}=100)$ of Eurasian barbines (Berrebi and Tsigenopoulos, 2003; Ráb and Collares-Pereira, 1995; Vasiliev, 1985) composed of 35 valid species widely distributed from the Iberian Peninsula in Western Europe to the Transcaspian region (the Atrek basin) in Central Asia (Eschmeyer, 2018). This lineage is phenotypically and genetically distinct from another tetraploid lineage of Eurasian barbels, the genus Luciobarbus (Doadrio, 1990; Doadrio et al., 2002; Levin, 2004).

The mitochondrial relationships of the European Barbus s. str. and the phylogeography of some species were clarified, mainly in the beginning of the 21 st century (Doadrio et al., 2002; Kotlík and Berrebi, 2001, 2002; Kotlík et al., 2004; Tsigenopoulos et al., 2002). Involvement of nuclear markers in this polyploid group promoted further uncovering of the evolutionary patterns of the Barbus diversity, an elaboration of the population structure, hybridization, and gene flow in certain groups of European barbels in Iberian (Gante et al., 2009, 2015; Machordom et al., 1990), Balkan (Marková et al., 2010), and Italian (Buonerba et al., 2015; Meraner et al., 2013) peninsulas. Molecular expertise coupled with morphological analysis resulted in the discovery of several new species, which were subsequently described as Barbus carpathicus Kotlík, Tsigenopoulos, Ráb and Berrebi, 2002 (Kotlík et al., 2002) and Barbus biharicus Antal, László and Kotlík, 2016 (Antal et al., 2016) from the Danube River, as well as some undescribed cryptic entities (Marková et al., 2010).

In contrast to the barbels from Western and Central Europe, Caucasian species appeared sporadically in some phylogenetic studies (Durand et al., 2002; Kotlík et al., 2004; Zardoya and Doadrio, 1999). Caucasus is a large mountain system located between the Black and Caspian seas and is considered to be one of the world's biodiversity 'hotspots' under conservation priority (Myers et al., 2000). Caucasian freshwater fish fauna is rich in endemism (Levin et al., 2018; Naseka, 2010). In fact, every second species in Caucasus ecoregions are endemic, 
according to a review of Naseka (2010). Five of six Caucasian barbels are considered Caucasian endemics (Berg, 1949; Naseka, 2010).

The Terek barbel B. ciscaucasicus Kessler, 1877 inhabits the Terek and Kuma riverine system; it is known from other tributaries of the Caspian Sea in East Ciscaucasia, southward from the Sulak basin to the Khudat R. and Kurakh-chai system in northern Azerbaijan (Abdurakhmanov, 1962; Bogutskaya, 2003a). Recently, the range of this species in East Transcaucasia was expanded ca. $100 \mathrm{~km}$ southward to the system of the dead-end Pirsagat R. (Gandlin et al., 2017). The Kura barbel B. cyri De Filippi, 1865 inhabits the extended Kura and Araks riverine systems, the Caspian Sea drainage, as well as the southward-located tributaries of the Caspian Sea until the Transcaspian Atrek basin (Bogutskaya, 2003b). The Sevan barbel $B$. goktschaicus Kessler, 1877 dwells in the large, isolated Lake Sevan and its tributaries (Bogutskaya, 2003c; Levin and Rubenyan, 2006). The Kuban barbel B. kubanicus Berg, 1912 inhabits the Kuban drainage, which is the extended riverine system of West Ciscaucasia. This species was also detected in the Manych system due to recent water diversion from the Kuban tributaries via canals (Poznyak, 1987); the Manych valley served in the past as a connecting passage between the Caspian and Black Sea basins (Esin et al., 2016). The Rioni barbel $B$. rionicus Kamensky, 1899, was described as originating from the Rioni basin, West Transcaucasia, but was later found to be synonymous with B. escherichii Steindachner, 1897 by Berg (1914). Based on recent taxonomic opinion, the Rioni barbel may be a valid species (Bayçelebi et al., 2015; Çiçek et al., 2016). The sixth Barbus species, Ankara barbel B. escherichii, is non-endemic to Caucasus. This species is distributed from the southwestern tributaries of the Black Sea in Anatolia, Turkey, to the Eastern Black Sea drainage on the Russian coast (Eschmeyer, 2017; Reshetnikov et al., 2003). We have to stress that some other Barbus species were described in Caucasus but were later transferred to synonyms of previously recognized species. Among these taxa are the Chorokh barbel B. artvinica Kamensky, 1899, the 
Toporovani barbel B. toporovanicus Kamensky, 1899, and the Bortschala barbel $B$. bortschalinicus Kamensky, 1899.

Although some genetic studies included the Caucasian Barbus species, they were based on few mitochondrial DNA sequences of the cytochrome $b(C y t b)$ or cytochrome oxidase I subunit (COI) of some species (Durand et al., 2002; Khaefi et al., 2017; Kotlík et al., 2004; Zardoya and Doadrio, 1999), while none of Caucasian taxa were sequenced for nuclear markers. This gap in knowledge of the genetic diversity and phylogeny of the significant part of the genus impedes studies on the phylogenetic organization of the Barbus s. str., and the evolutionary history of Caucasian species as well as their taxonomy.

The purposes of the present study were i) to estimate phylogenetic relationships, ii) to clarify phylogeography and iii) to contribute to the taxonomy of the Caucasian barbels of the genus Barbus s. str. of all the abovementioned Caucasian taxa with wide geographic coverage from Armenia, Azerbaijan, Georgia, and Russia. We also aimed to verify the hybridization among Caucasian taxa, given that such events were repeatedly reported for the Barbus from Central and Southern Europe (Buonerba et al., 2015; Lajbner et al., 2009; Machordom et al., 1990; Meraner et al., 2013). For these purposes, we used the datasets of two mitochondrial markers and one nuclear marker.

\section{Material and methods}

\subsection{Sampling, DNA extraction, and sequencing}

DNA samples were collected from 277 individuals of Caucasian and Crimean Barbus with local authority permission. All Barbus species of this region were collected from 81 sampling sites of the drainages of the Black and Caspian Seas, including the type localities or type basins, except that for B. escherichii, which was described by Steindachner (1897) as originating from the Sakarya River, Turkey (Table S1-S2, Figure 1). The mursa Luciobarbus mursa (Güldenstädt, 
1773) and the khramulya Capoeta capoeta (Güldenstädt, 1773) were also sampled for DNA extraction, PCR and subsequent phylogenetic analysis in the Caucasian rivers (Table S1) as outgroups according to previous phylogenetic studies (Levin et al., 2012; Tsigenopoulos et al., 2003). A fragment of pelvic fin was cut and stored in microtubes in $96 \%$ ethanol and deposited in the IBIW RAS Ichthyological collection. DNA-vouchers from each site were killed with overdoses of MS222 and preserved in $10 \%$ formalin or $96 \%$ ethanol and stored in the IBIW RAS Ichthyological collection.

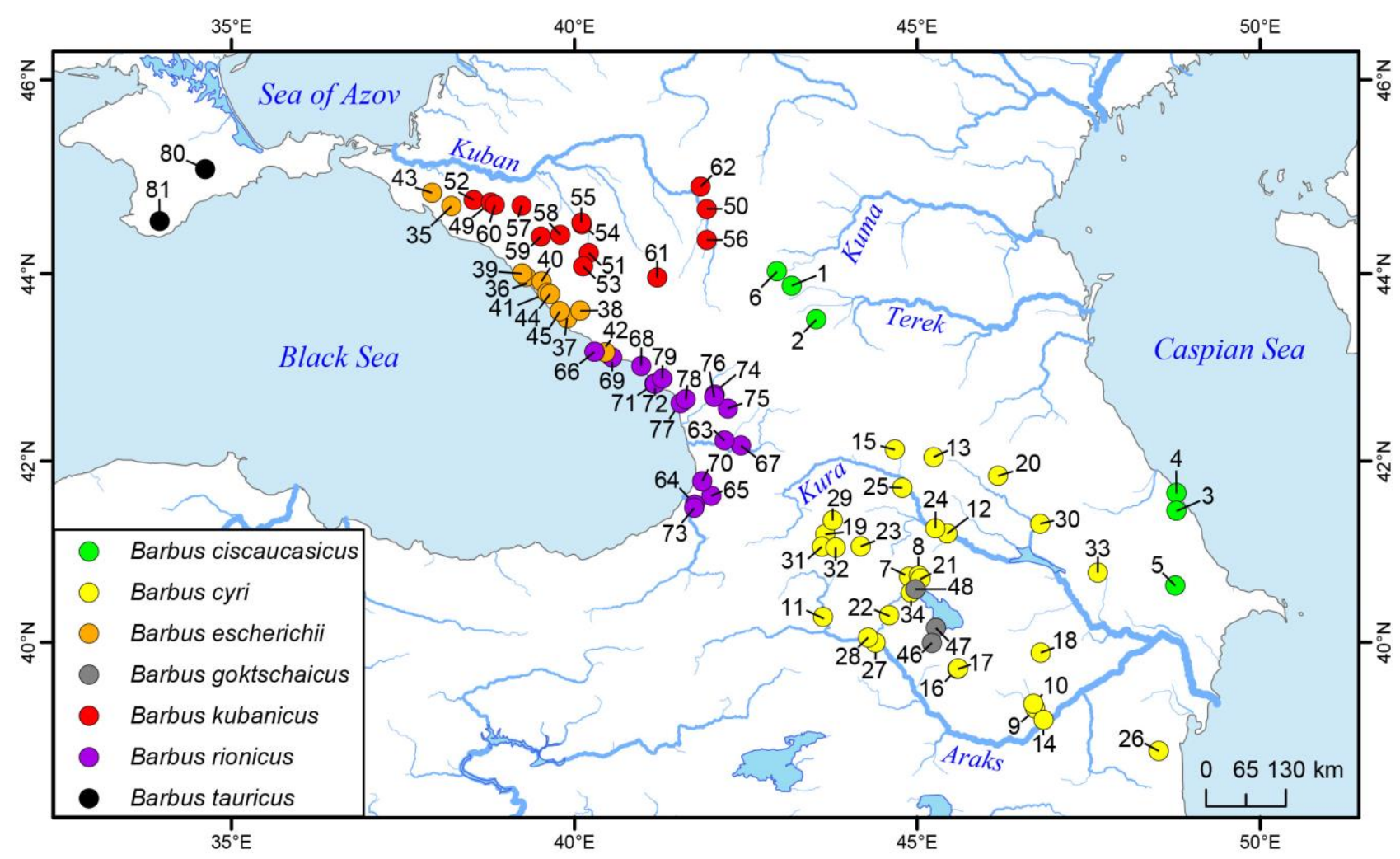

Fig. 1. Map of sampling locations. See Table S1 for the corresponding localities numbers.

DNA was extracted using the salt method (Aljanabi and Martinez, 1997). Two mitochondrial markers (barcoding cytochrome oxidase subunit I - COI, and cytochrome $b$ $C y t b$ ) and one nuclear marker (second intron of beta actin gene - Act-2) were amplified using specific primers (Table 2). Barbels are tetraploid with a chromosome number of $2 n=100$, so that the primers were designed to selectively amplify a single paralogous copy of Act-2 (Marková et 
al., 2010). The PCR conditions followed protocols from Ivanova et al. (2007) for COI, Levin et al. (2012) for Cytb, and Marková et al. (2010) for the Act-2 second intron.

Table 1.

Sequencing of the PCR products purified by ethanol and ammonium acetate $(3 \mathrm{M})$ precipitation was conducted using the Applied Biosystems 3500 DNA sequencer with forward sequencing primer M13F 5'-GTA AAA CGA CGG CCA GT-3' and reverse sequencing primer M13R-pUC 5'-CAG GAA ACA GC T ATG AC-3' (Geiger et al., 2014) for COI and PCR primers for $C y t b$ and $A c t-2$. The obtained sequences were deposited into the GenBank database (see Table S1 for accession numbers).

\subsection{Analysis of mtDNA data}

The nucleotide sequences of $C y t b$ and $C O I$ were manually aligned, edited, and checked for unexpected stop-codons using SeaView 4.4.2 (Gouy et al., 2010). The sequences were collapsed into haplotypes. Phylogenetic reconstruction was performed using the maximum-likelihood (ML) and the Bayesian inference (BI) approaches on each marker, both separately and combined. Before running phylogenetic analyses, the datasets were tested for redundancy and saturation using METAPIGA 3.01 (Helaers and Milinkovitch, 2010). We determined the best fit models of nucleotide substitution and the optimal partitioning scheme for each marker and combined the dataset using either IQ-TREE 1.5.4 (Nguyen et al. 2015; Kalyaanamoorthy et al. 2017) or PartitionFinder 2.1.1 (Lanfear et al., 2012) under the Bayesian Information Criterion (BIC). The partition schemes selected by IQ-TREE (Table 2) were subsequently used in the ML search with the same software, using 1000 ultrafast bootstrap replicates (Minh et al., 2013). 
Table 2.

The following settings were common for all MrBayes runs: the sampling frequency was every 500 generations, and the first $25 \%$ of generations were discarded as burn-in. Convergence of runs was assessed by examination of the average standard deviation of split frequencies and the potential scale reduction factor. In addition, stationarity was confirmed by examining the posterior probability, log likelihood, and all model parameters by the effective sample sizes (ESSs) in the program Tracer v1.6 (Rambaut et al., 2014). The phylogenetic trees resulting in ML and BI analyses were visualized and edited using FigTree v.1.4.3 (Rambaut, 2008).

The number of haplotypes $(\mathrm{H})$, haplotype diversity $(\mathrm{h})$, nucleotide diversity $(\pi)$, number of segregating sites $(\mathrm{S})$, and average number of nucleotide substitutions $(\mathrm{K})$ were calculated using DnaSP v.5.10 (Librado and Rozas, 2009). Haplotype networks were built with the help of PopART 1.7 software (Leigh and Bryant, 2015) using the median-joining algorithm (Bandelt et al., 1999).

Divergence times between the Barbus species were estimated in BEAST 1.8 (Drummond et al., 2012) using a relaxed molecular clock with an uncorrelated lognormal distribution and a Yule speciation prior (Drummond et al., 2006). Cytb sequences of the Barbus species set were used for phylogeny as well as for comparative sets of the Capoeta and Luciobarbus species, some sequences of which were obtained from GenBank (Table S2). A total of 215 sequences with the length of a fragment of $C y t b=993$ bp were analyzed. Outgroups were Cyprinus carpio (AY347287), Cyprinion macrostomus (AF180826), and Aulopyge huegelii (AF287416). The following calibration points were selected: (1) fossil evidence of the Barbus species (18-19 Mya, Czech Republic, several localities - Böhme and Ilg, 2003); (2) fossil evidence of the Luciobarbus genus (16.9-17.7 Mya, Turkey, Belenyenice - Böhme and Ilg, 2003); (3) fossil 
evidence of the Iberian Peninsula Luciobarbus species (5.33-7.05 Mya) (Doadrio and Casado, 1989; García-Alix et al., 2008). The substitution models by codon position were selected in PartitionFinder 2.1.1: K80+I+G, HKY+I, TN93+G. The user-specified starting tree was used. The tree was generated with MrBayes and then transformed into an ultrametric, time-calibrated tree using a penalized likelihood approach (Sanderson, 2002) implemented using the 'chronos' function of the 'ape' R package (Paradis et al., 2004). Each final MCMC chain was run for $10^{8}$ generations (20\% burn-in), with parameters sampled every 1000 steps. Tracer 1.6 (Rambaut and Drummond, 2013) was used to evaluate the run convergence and effective sample sizes for all parameters. The trees were summarized with TreeAnnotator 1.7 (Drummond et al., 2012) to obtain a maximum clade credibility tree.

\subsection{Analysis of nDNA data}

Heterozygotes of individual sequences of Act-2 were identified by double peaks in the chromatograms. All polymorphic sites were carefully inspected to ensure consistent identification of such positions. The sequences were aligned using Muscle 3.8.31 (Edgar, 2004). Alleles (haplotypes) of the Act-2 were inferred using Phase version 2.1 (Stephens and Donnelly, 2003; Stephens et al., 2001) with 1000 burn-in steps and 1000 iterations. Some individuals carried alleles of different sizes due to insertion/deletion polymorphisms, as shown by the offset chromatogram peaks. Due to this constraint of using software that is commonly used for phase data, haplotypes were thus manually phased using the method described by Sousa-Santos et al. (2005) and Flot et al. (2006). The phylogenetic network between studied species was resolved by a statistical parsimony algorithm implemented in TCS 1.21 (Clement et al., 2010). The method was selected due to its ability to handle indels (gaps) as $5^{\text {th }}$ state. However, the software considers each gap position within an alignment as a single mutation, which is a very implausible scenario for the origin of indels. To overcome this shortcoming, we cut all deletions 
within the alignment to the length of one bp. After such modification, each indel was handled by TCS as a single mutation event, which creates a much more probable model. Given that clipped fragments did not contain any nucleotide substitutions, this approach allowed us to use all sources of variability without any information loss. The nucleotide variability of Act-2 sequences were described in the same way as for the mtDNA loci. Both alleles for each individual were accounted for in all analyses.

\section{Results}

\subsection{Mitochondrial DNA sequence analyses}

Based on the Cytb sequences, 27 studied species of the Barbus s. str., including the Caucasian taxa from the monophyletic cluster that is sister to the Aulopyge, Luciobarbus and Capoeta species group (Fig. 2), confirmed the results of previous phylogenetic studies (Levin et al., 2012; Machordom and Doadrio, 2001; Tsigenopoulos et al., 2003). One individual of the Sevan barbel B. goktschaicus had a haplotype of the algae eater, Sevan khramulya C. capoeta (Fig. 2, Fig. S1), which is an evolutionary hexaploid ( $2 n=150$, see Krysanov, 1999), suggesting introgressive hybridization between the tetraploid Barbus and hexaploid Capoeta lineages. 


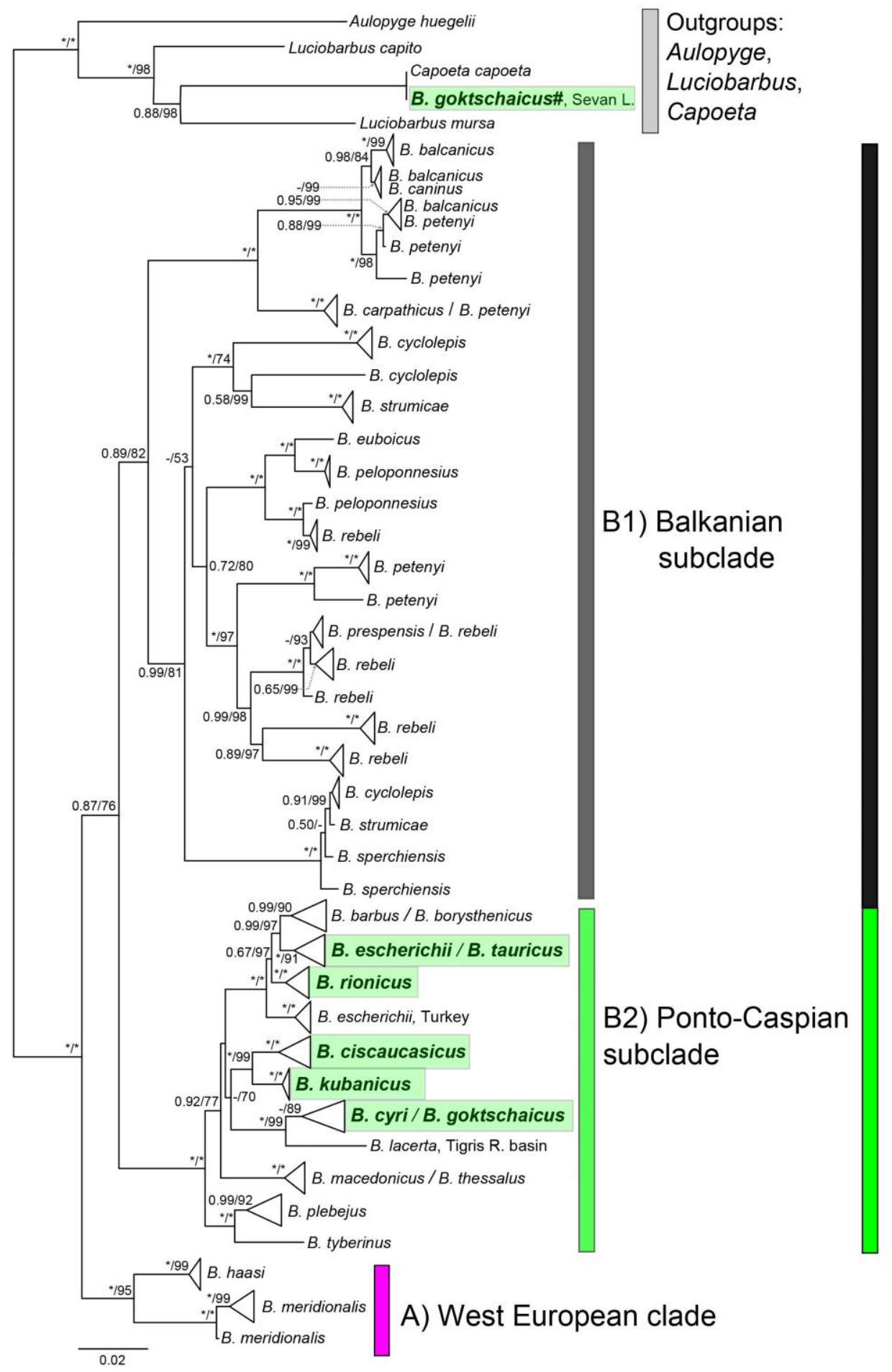

B) Central and East European clade

Fig. 2. BI consensus gene tree based on the partial Cytb sequences (993 bp long) for 27 Barbus species. Bayesian posterior probabilities (on the left side) and bootstrap values from a ML analysis (on the right side) above 0.5/50 are shown; asterisks represent posterior probabilities/bootstrap values of 1/100. Caucasus taxa are highlighted in green. The nodes with multiple specimens were collapsed to a triangle, with the horizontal depth indicating the level of divergence within the node. One individual of $B$. goktschaicus had the same haplotype as C. capoeta and considered as a hybrid (marked with \#). Scale bar and branch lengths are in expected substitutions per site. 
According to both ML and BI analyses, the genus Barbus is subdivided into two main clades: A) the West-European clade with two species - B. haasi and B. meridionalis and B) the remaining species from Central and Eastern Europe. This last group (B) is composed of two subclades: B1) the largest and most diversified Balkanian group of barbels, with moderate support, which includes $12-13$ species, mostly from the Balkan peninsula, and B. caninus from Northern Italy; and B2) the Ponto-Caspian subclade that includes all Caucasian species, one species from the Tigris-Euphrates basin (B. lacerta), two species from the Balkan Peninsula (B. macedonicus and B. thessalus) and two species (B. plebejus and B. tyberinus) distributed in the Apennine Peninsula and the Western part of the Balkan Peninsula. Within the last subclade, two main monophyletic groups were recovered, one with Ponto-Caspian species and the other with the species of the Italian and Western Balkanian area. The most basal group among all Barbus spp. is composed of the mainly Iberian species, B. meridionalis and B. haasi.

Data on the $C O I$ marker confirmed the presence of the main inner clades of Barbus that was revealed by the $C y t b$ analyses; however, the phylogenetic utility of the COI marker to resolve inner relationships was low (Table S3, Fig S1). The combined dataset $C y t b+C O \mathrm{I}$ analyses confirmed the presence of main clades in Barbus and its sister relationships to Luciobarbus + Capoeta, which were revealed by the Cytb marker.

\subsubsection{Intrarelationships of Ponto-Caspian subclade}

The Ponto-Caspian subclade includes 11 lineages distributed mainly in the basins of the Black Sea [5 lineages: i) B. barbus + B. borysthenicus; ii) B. tauricus + B. escherichii; iii) B. rionicus; iv) Barbus sp. from Turkey, and v) B. kubanicus - all these lineages were numbered according to the lineages delineated by Kotlík et al. (2004) for Black Sea drainage barbels] and the Caspian Sea [3 lineages: vi) B. ciscaucasicus, and vii) B. cyri + B. goktschaicus, as well as viii) B. lacerta lineage from the drainage of the Persian Gulf, Arabian Sea basin], ix) the Aegean lineage that 
comprises B. macedonicus and B. thessalus from the Aegean Sea drainage, $\mathrm{x}$ ) the B. plebejus lineage distributed in the Western Balkans and in the Apennine Peninsula, and xi) the $B$. tyberinus lineage from the Apennine Peninsula (Fig. 2).

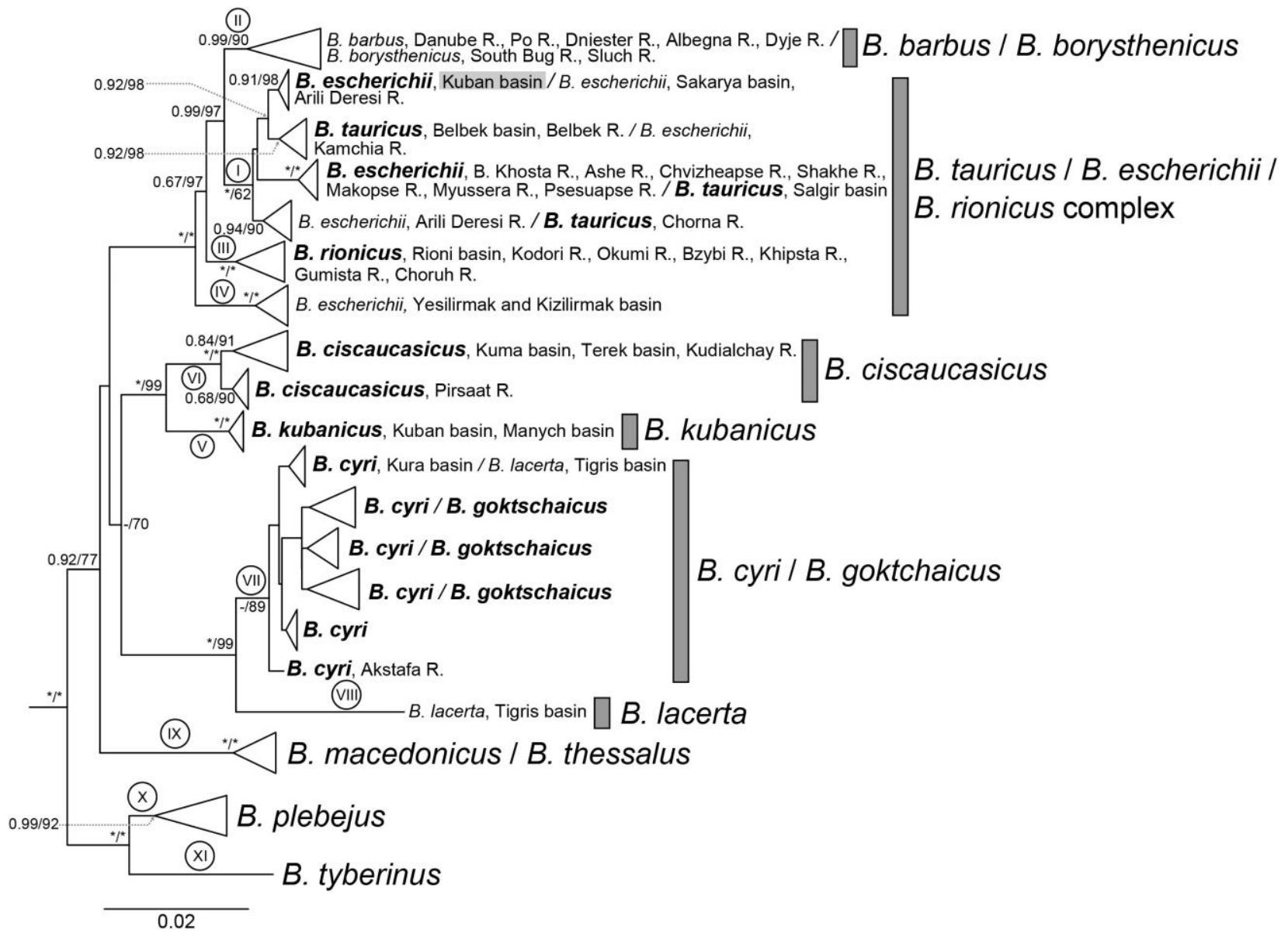

Fig. 3. The enlarged fragment of BI consensus gene tree (Fig. 2) displayed the Ponto-Caspian species inside B2 subclade based on the 69 unique haplotypes of Cytb sequences (993 bp long). Bayesian posterior probabilities (on the left side) and bootstrap values from a ML analysis (on the right side) above $0.5 / 50$ are shown; asterisks represent posterior probabilities/bootstrap values of $1 / 100$. Lineages from I to V corresponds to such in study of Kotlík et al. (2004). The species B. escherichii detected in the Kuban basin is highlighted with grey. Scale bar and branch lengths are in expected substitutions per site.

The Caucasian barbel species are clustered into three groups: a) the Black Sea group, which includes all Black Sea species, except for B. kubanicus; b) the Caspian group, which includes B. cyri with B. goktschaicus (the latter does not differ from the former genetically - see Table S3; both inhabit the Kura-Araks system), and B. lacerta, which is the sister to B. cyri and inhabits the Tigris-Euphrates drainage adjacent to the Kura-Araks drainage, and c) the 
Ciscaucasian group, which is composed of B. ciscaucasicus, which inhabits some northern tributaries of the Caspian Sea, and B. kubanicus, which inhabits the Kuban basin (Azov Sea drainage) and is sister to B. ciscaucasicus. All of the Caucasian species combined are sister to the group of the two Aegean species: B. macedonicus and B. thessalus. The Aegean lineage is deeper diverged compared to the Caucasian lineages. The outer group in the Ponto-Caspian subclade is B. plebejus + B. tyberinus, which is a westward distributed species.

The divergence between members of the Ponto-Caspian subclade is less than between species of another large subclade, the Balkanian subclade (Fig. 2), which suggests the younger origin of the Ponto-Caspian species (see section 3.3. Molecular clock).

\subsubsection{Phylogeography of Black Sea coastal B. tauricus / escherichii / rionicus complex}

Populations of the Black Sea group have a rather complicated phylogeography. This group is characterized by 24 Cytb haplotypes subdivided into three main haplogroups (Fig. 4). The most diverged haplogroup includes the B. tauricus / B. escherichii complex with 12 haplotypes. The Crimean barbel B. tauricus, with a restricted range to rivers in the Crimean Peninsula, has only one shared haplotype with barbels from other populations. Despite that, its haplotypes are very divergent among each other and are closer to haplotypes from the geographically remote populations of B. escherichii (Black Sea tributaries in Turkey and Bulgaria) or closely located ones (rivers of Russian coast of Black Sea) (Fig. 5). The species B. tauricus also had the highest nucleotide diversity (Table 3).

We have to note that B. escherichii has been detected in the Kuban basin for the first time, where from only $B$. kubanicus was previously reported. Remarkably, the Kuban haplotypes of $B$. escherichii are closer to or share the same haplotypes with populations from the southern coast of the Black Sea in Turkey (the Sakarya basin and the Arili Dereseli R. near Rize city) but are 
adjacent to the B. escherichii from the Russian coast of Black Sea (the rivers between Sochi and Tuapse).

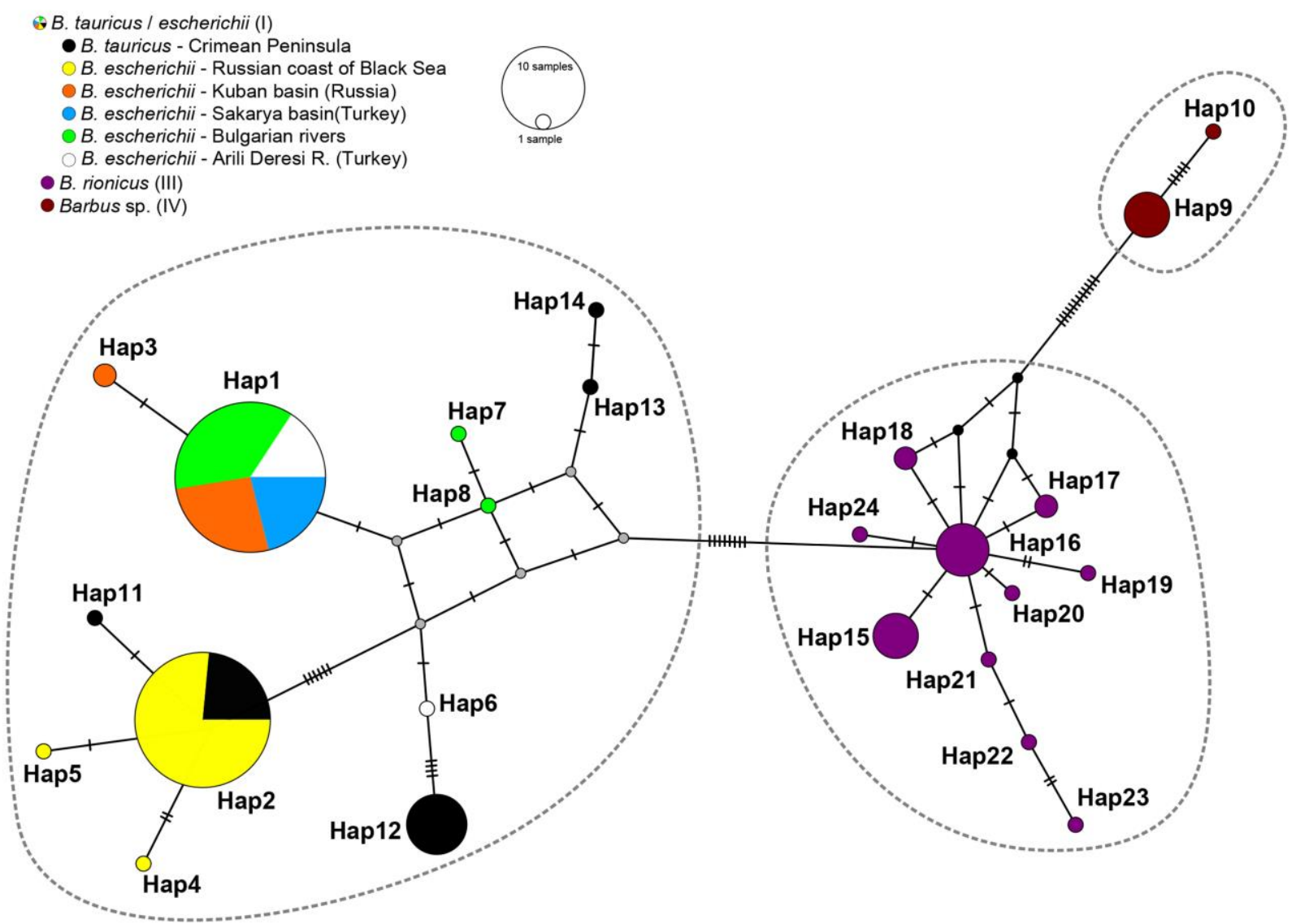

Fig. 4. Median-joining haplotype network of Black Sea barbs B. tauricus / escherichii / rionicus complex constructed on $C y t b$ sequences. The circle sizes correspond to relative haplotype frequencies. One vertical mark denotes one substitution. Small grey circles represent hypothetical intermediate haplotypes.

There are two other distinct haplogroups, which are distant to B. tauricus/escherichii complex and to each other, and which represent B. rionicus and Barbus sp. (assigned as lineage iv in study of Kotlík et al., 2004). The species B. rionicus is widely distributed from the Choruh basin along the Georgian coast to the Bzyb River and has a star-like pattern of 10 haplotypes (Fig. 1 \& 5). The most diverged haplogroup represents two haplotypes from the center of the Southern coast of the Black Sea in Turkey (Kizilirmak and Yesilirmak basins) and are assigned here as Barbus sp.

Table 3. 


\subsubsection{Phylogeography of the Kura barbel Barbus lacerta and Sevan barbel B. goktscaicus}

The Sevan barbel B. goktschaicus is represented by nine haplotypes $(h=0.910)$, two of which are shared with haplotypes of B. cyri (Fig. 5). The other seven haplotypes are not divergent from $B$. cyri, which is represented by 21 haplotypes $(h=0.933)$. The $P$-distance between these two species is minute (0.003). The most divergent haplotype of $B$. cyri (8 mutational steps from the ancestral haplotype) was detected from the Qarachai R. (loc. 30), a northern tributary of the Kura R. The species B. lacerta inhabited the Tigris-Euphrates system and, being sister to B. cyri, had 28 mutational steps to the nearest haplotype of the latter.

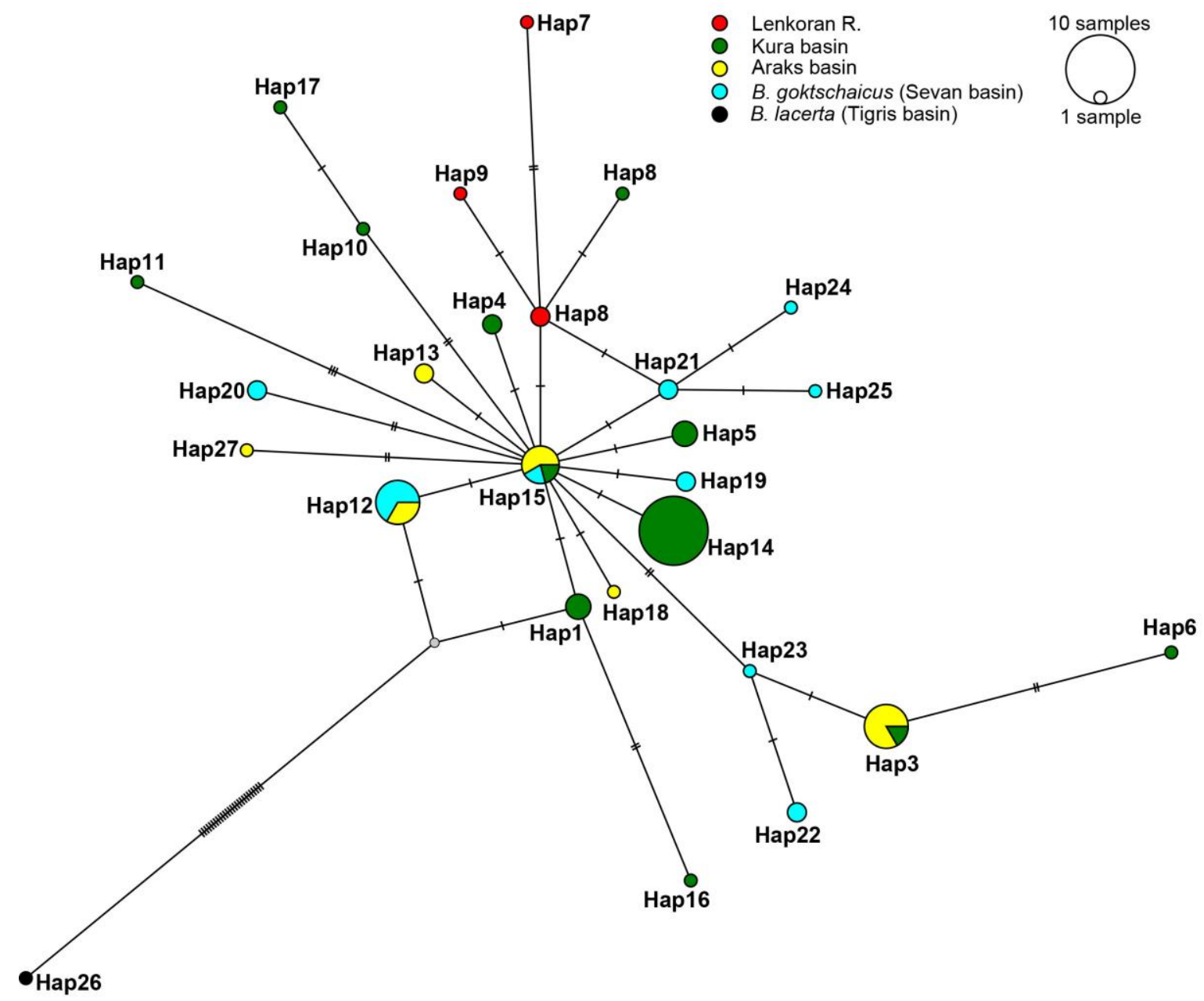

Fig. 5. Median-joining haplotype network of B. cyri / goktschaicus constructed on Cytb sequences. The circle sizes correspond to relative haplotype frequencies. One vertical mark denotes one substitution. Small grey circles represent hypothetical intermediate haplotypes. 


\subsection{Intron 2 beta actin data set}

The statistical parsimony network generated by TCS is not very diversified (Fig. 6). All Caucasian barbel species are characterized by 16 unique alleles of Act-2. The most frequent allele has an ancestral position and was formed by individuals of the Caucasian species (B. cyri, B. goktschaicus and B. escherichii) and some individuals of the Balkanian species (white color). Moreover, this is the only allele shared between the Balkanian and Ponto-Caspian subclades. More diversified representatives of the Balkanian subclade, with 26 different alleles of six species (sample size 40 individuals) compared to 16 alleles of six Caucasian and one Crimean species (52 individuals) coupled with mtDNA data, suggest a younger origin and shallower intradivergence of the Ponto-Caspian subclade.

Table 4.

The Ciscaucasian species B. ciscaucasicus and B. kubanicus are distinct from other species (four mutational steps to both 'ancestral' alleles or Balkanian species). These species are close to each other and are rather monomorphic (Table 4), having two main species-specific alleles and one allele shared by a single individual of both species (Fig. 6). The shared haplotype could suggest both hybridization in the past or a retention of ancestral polymorphism due to incomplete lineage sorting (ILS).

The sharing of the same allele by B. kubanicus and B. escherichii recorded in the Kuban basin provides evidence for the hybridization between these species rather than ILS, since other populations of the B. escherichii / tauricus / rionicus complex had no shared alleles with $B$. kubanicus (Fig. 6). Notably, all studied individuals of B. escherichii that penetrated into the Kuban basin had species-specific mtDNA haplotypes (Fig. 4), while six of them were 
heterozygous in Act-2 and possessed one allele specific to B. kubanicus, an endemic species of the Kuban river system (Fig. 6). Furthermore, four individuals in the Kuban population were assigned to $B$. escherichii based on their mtDNA being homozygous with the allele specific to $B$. kubanicus, i.e., were fully introgressed.

The complex B. tauricus / escherichii / rionicus is the most diversified by the nuclear marker representing eight alleles, excluding the supposed hybrids from the Kuban R. This diversification, however, provides no evidence of the genetic subdivision of the species of this complex based on Act-2 and suggests that the recent origin and likely secondary contacts were between isolated and semi-isolated populations.

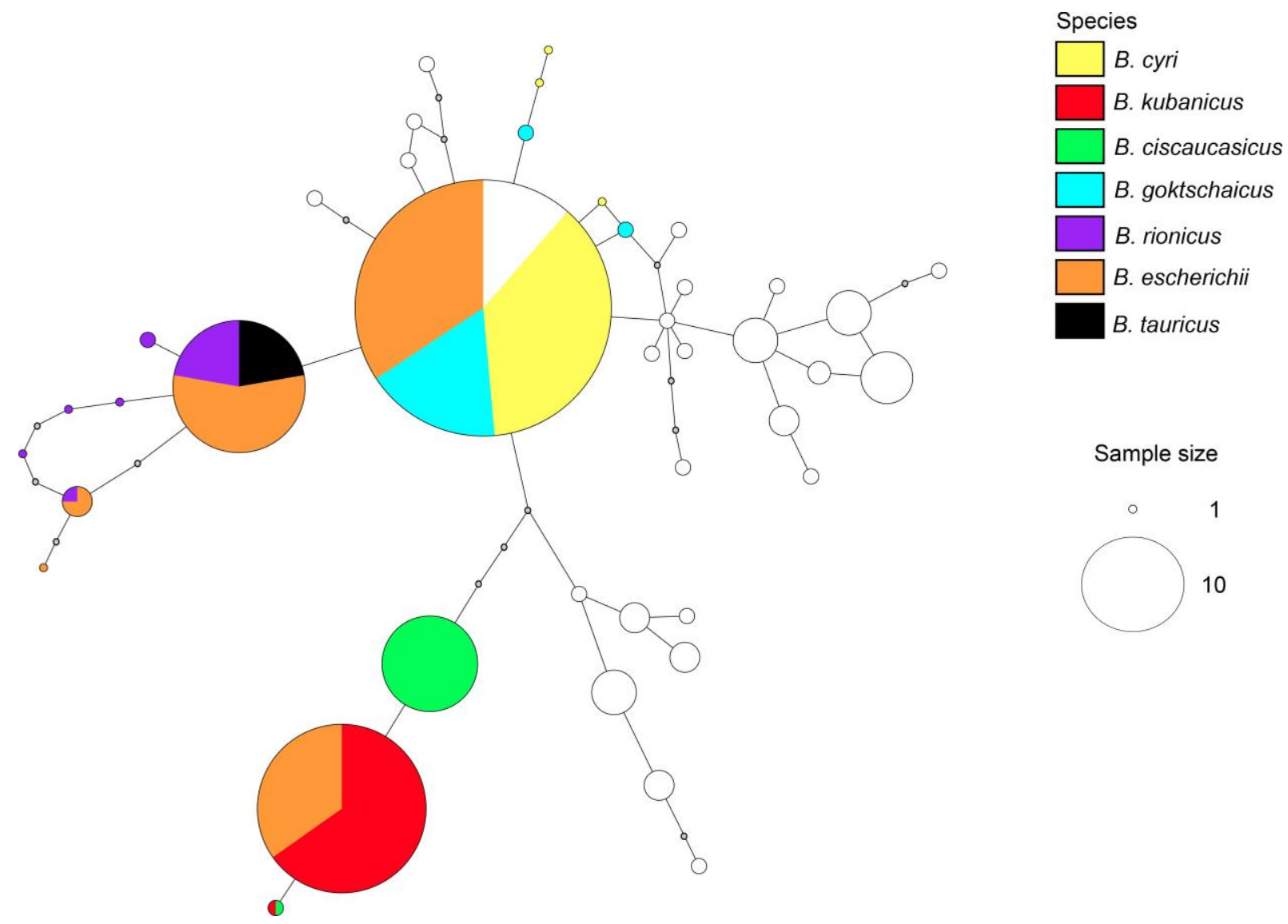

Fig. 6. Statistical parsimony network of Caucasian barbels constructed on Act-2 phased sequences. Empty circles represent alleles of Balkanian species B. balcanicus, B. petenyi, B. prespensis, and B. rebeli from study of Antal et al. (2016). The circle sizes correspond to relative allele frequencies. Small grey circles represent intermediate mutational steps.

\subsection{Molecular clock}


Divergences between the well-established genera Barbus and Luciobarbus were estimated to have occurred in the Late Oligocene-Early Miocene sub-epoch (95 \% HPD: 19.26-24.43 MyaFig. 8), which is close to the previously obtained results (Ghanavi et al., 2016; Levin et al., 2012). A separation of the Ponto-Caspian subclade from the Balkanian subclade was estimated to occur during the Middle Miocene sub-epoch approximately 16.94 Mya (95 \% HPD: 14.8218.76 Mya). The divergence of the Balkanian species of the Ponto-Caspian subclade ( $B$. macedonicus and $B$. thessalus lineage) and of the Ponto-Caspian species themselves was estimated to have occurred in the Late Miocene sub-epoch approximately 10.26 Mya (95\% HPD: 7.12-13.58 Mya). The lineage of Ponto-Caspian barbels was early diverged for Black Sea and Caspian Sea groups approximately 9.45 Mya (95 \% HPD: 6.46-12.50).

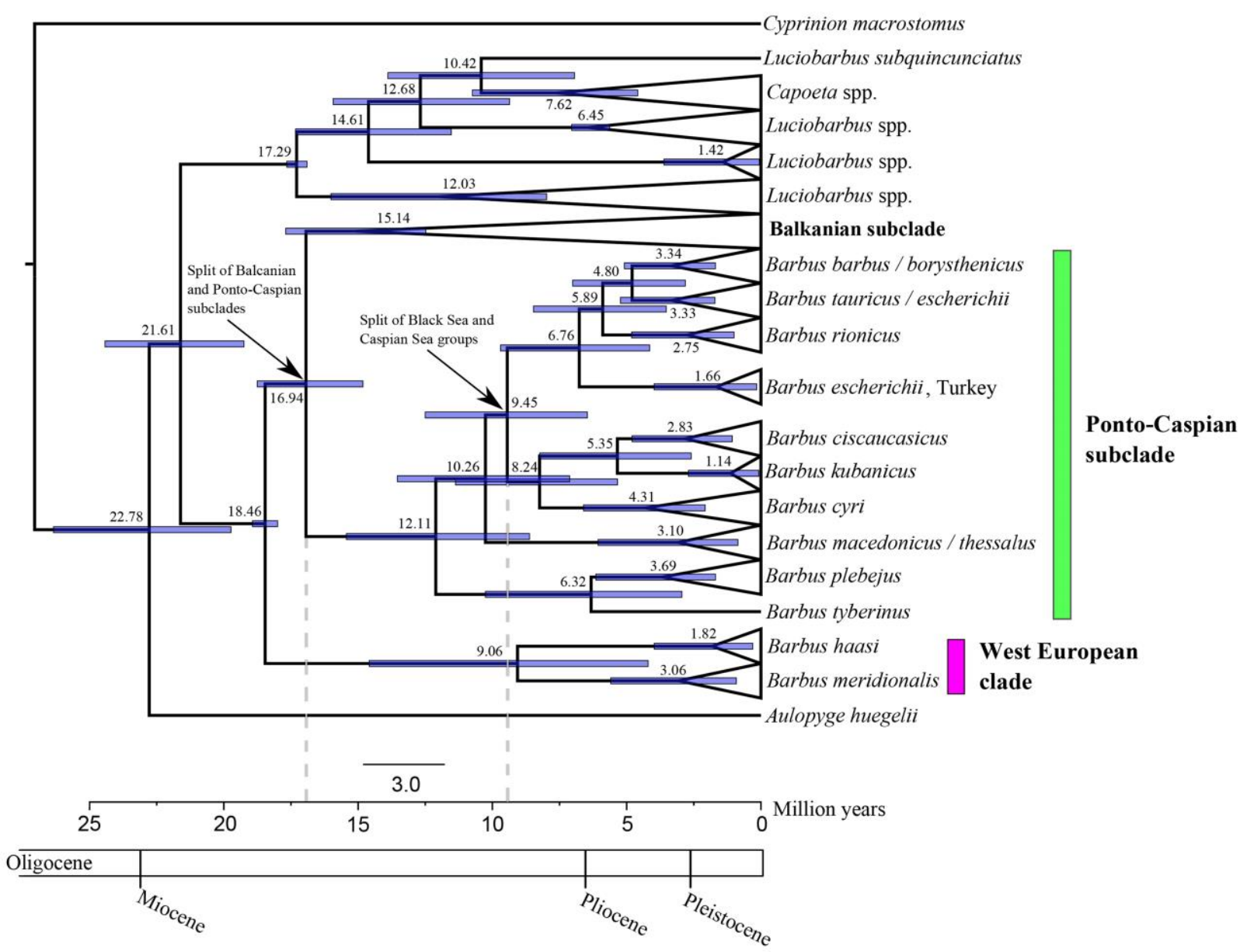

Fig. 7. Divergence time (Mya) and credibility intervals (95\% highest posterior density). All nodes were highly supported at $\mathrm{PP}=1$ (not shown on tree). 


\section{Discussion}

\subsection{Phylogeny of the genus Barbus and position of Caucasian barbels}

The phylogenetic relationships of the genus Barbus s. str. have been reported in several studies based on the Cytb marker (Berrebi and Tsigenopoulos, 2003; Kotlík and Berrebi, 2002; Zardoya and Doadrio, 1999). However, all Caucasian barbels represented by seven species were unstudied. The phylogeny constructed by BI and ML approaches in the present study is based on the mtDNA sequences of 27 species of Barbus s. str., which are clustered for two clades. The earlier diverged clade is the West European clade with two species, B. meridionalis and B. haasi. The presence of this clade was shown in previous phylogenetic studies, however, without separation and naming (Berrebi and Tsigenopoulos, 2003; Zardoya and Doadrio, 1999). The second, much diversified clade of barbels from Central and East Europe includes all other species with deeply diverged lineages, especially in the Balkans. The inner phylogeny of the Balkanian subclade deserves special attention and should be studied more thoroughly, which is beyond the scope of the present study.

The diversified Balkanian subclade is sister to the Ponto-Caspian subclade. The divergence of these subclades probably occurred ca. 17 Mya, according to our molecular clock (Fig. 7), during one of the Alpine orogeny phases and was accommodated by a continuing collision of the Afro-Arabian plate with the Eurasian plate (Jolivet and Facenna, 2000). This date is close to that which was reported in a previous study (15.7 Mya), which was based on the restricted number of Barbus species (Levin et al., 2012). However, the divergence between Caucasian and West Balkan cave shrimp Troglocaris was estimated to occur earlier, at approximately 6-11 Mya based on COI and 16S markers (Zakšek et al., 2007). Earlier diverged lineages inside the PontoCaspian subclade are represented by lineages of B. tyberinus and B. plebejus, which are distributed in the Apennine Peninsula and South-Western Balkans. They are sister to nine other lineages, seven of which are Caucasian, that are distributed in the basins of the Black and 
Caspian Seas. Two other lineages branched earlier, including the Aegean species ( $B$. macedonicus and B. thessalus - lineage ix) and the Mesopotamian species (B. lacerta from the Tigris-Euphrates basin Arabian Sea drainage - lineage viii).

The present study confirmed the relatedness of two Balkanian barbel species that inhabited the Aegean Sea drainage to Caucasian barbels (Levin et al., 2012) in the Ponto-Caspian subclade. The Balkanian drainage of the Aegean Sea shares a watershed with the western part of the Black Sea drainage. There are genetic evidence of the close relationships between Caspian lamprey Caspiomyzon wagneri, which inhabited the Caspian Sea and the 'Eudontomyzon' hellenicus, which inhabited the Struma basin (Lang et al., 2009), or even the occurrence of Ponto-Caspian fish species in the water bodies of the Aegean Sea drainage (Levin et al., 2017; Tsoumani et al., 2014).

Caucasian barbels are composed of two main lineages, Black Sea and Caspian lineages, which are represented mainly by species of the Black Sea drainage (except for B. kubanicus) and species of the Caspian Sea drainage (including B. lacerta from the Tigris-Euphrates) (Fig. 2). Based on early branching of these two main lineages, they were split early after the colonization of the Ponto-Caspian basin. According to our molecular clock, a separation of groups of Caucasian barbels of the Black and Caspian Seas groups occurred during the Lower Miocene sub-epoch approximately 9.45 Mya (Fig. 7), which was a period of intensive elevation of the Caucasian region and occurred when the modern relief was forming (Lazukov, 1989). The Suram (or Likhi) range in Transcaucasia that separated the drainages of the Black and Caspian seas raised ca. 10-15 Mya and has fully isolated the Western and Eastern parts of Transcaucasia ca. 10 Mya (Maruashvili, 1981). The Caspian lineage is more diversified and includes three groups: a) the Mesopotamian species B. lacerta, b) the Eastern Transcaucasian species B. cyri / goktschaicus, and c) the Ciscaucasian sister species B. ciscaucasicus and B. kubanicus. The intra-Caucasian divergence occurred from 6.76 to 4.80 Mya based on our molecular clock (Fig. 7), which coincides with a period of active uplift of both the Great and Lesser Caucasus, as well 
as the Pliocene volcanism in Transcaucasia (Lazukov, 1989). The possible reasons for shallower divergence between the Circum Black Sea species will be considered below.

Based on the phylogeny of the Barbus s. str. and the degree of diversification among the different subclades, we hypothesize that the genus could have originated from the common ancestor of Luciobarbus/Barbus, whether in A) Western Europe and further dispersed into Central and Southern Europe (mainly Balkans), or in B) Balkanian Europe and further distributed throughout Europe and penetrated into Minor Asia and Caucasus. The Balkan region is a European biodiversity hotspot that was suggested as a refuge area for fish species (Oikonomou et al., 2014; Tsigenopoulos, 1999; Zardoya et al., 1999). The West European clade branched earlier compared to other clades; however, i) differences in the branching distance are not large, ii) the Balkanian clade is much more diversified, and iii) the most ancient Balkanian species could become extinct during some of climatic oscillations or geological events. The latter reason indicates that the West European species might look more ancient. Currently, we cannot provide support any of these hypotheses on the origination of the genus until we obtain more data.

\subsection{Hybridization and introgression}

Interploidy hybridization between hexaploid C. capoeta sevangi $(2 \mathrm{n}=150$ - Krysanov, 1999) and tetraploid B. goktschaicus (2n=100 - Krysanov, 1999) in Lake Sevan (Armenia) was recognized in the phenotypically B. goktschaicus individual that possessed the mtDNA of C. capoeta sevangi. Moreover, the short fragment of the nuclear marker Act-2 of Capoeta was also detected in this hybrid specimen. It is the first evidence of the hybridization between these genera. Natural intergeneric hybrids between Capoeta damascina $(2 \mathrm{n}=150$ according to Gorshkova et al., 2002) and Luciobarbus longiceps (not karyotyped, but should be a tetraploid based on its phylogenetic position - see Tsigenopoulos et al., 2003) were repeatedly reported from Lake Kinneret, Israel 
(Abraham, 1996; Stoumboudi et al., 1992, 1993). Interploidy hybridization is an apparent evolutionary mechanism for the origination of new polyploid fish lineages, including Capoeta (Chenuil, 1999; Levin et al., 2012; Yang et al., 2015), and the cases of such hybridization have to be studied more thoroughly.

While intergeneric hybrids are rarely recorded, interspecies hybridization inside the genus Barbus s. str. is a more common phenomenon. For instance, hybridization and introgression were detected between the species of the Western European clade B. meridionalis and B. haasi (Machordom et al., 1990), between B. barbus and B. meridionalis in France (Berrebi et al., 1993; Crespin et al., 1999), B. barbus and B. carpathicus in Slovakia (Lajbner et al., 2009), B. barbus and B. plebejus, B. balcanicus and B. plebejus, and B. caninus and B. plebejus in Italy (Buonerba et al., 2015; Meraner et al., 2013; Tsigenopoulos et al., 2002). In some cases, the asymmetrical hybridization with disproportionate contribution of B. barbus mothers was detected (Lajbner et al., 2009; Meraner et al., 2013). Moreover, in the case of B. barbus and B. carpathicus, no $\mathrm{F}_{2}$ progeny or backcrosses to B. carpathicus were found (Lajbner et al., 2009).

Hybridization between Ponto-Caspian barbels is reported for the first time in the present study. The case of hybridization between B. escherichii and B. kubanicus was established after finding B. escherichii in the Kuban basin (reported in this study for the first time). We interpret this event as a natural hybridization during secondary contact. The Kuban population of $B$. escherichii had mtDNA haplotypes similar to the remote conspecific Turkish populations. In our opinion, this is a relict population that resulted from one of the migration waves that occurred during the freshwater phases of the Black Sea (see a more detailed discussion in the subsection below). Remarkably, all sampled Kuban specimens of B. escherichii have their own speciesspecific mtDNA haplotypes, but a nuclear marker revealed that several individuals had the nuclear genome of B. kubanicus, and some were heterozygous. First, it gives evidence that hybridization occurred in the past and is ongoing (heterozygous specimens may be F1 hybrids or backcrosses). Second, it may reveal asymmetrical hybridization, as reported previously for 
several European species of barbels (Buonerba et al., 2015; Crespin et al., 1999; Lajbner et al., 2009; Meraner et al., 2013). The obtained results show that the hybridization of two barbel species in the Kuban basin needs further investigation.

\subsection{Mosaic dispersal of lineages in Black Sea drainage}

The spatial heterogeneity of the haplotype structure of different lineages in the Black Sea drainage is common for all studied taxa, except for $B$. rionicus, which inhabited the southeastern part of Black Sea basin and has unique haplotypes (Fig. 4, 6). In our view, the mosaic dispersal of mtDNA haplotypes is rather a consequence of the secondary contacts of different lineages during the freshwater phases of Black Sea over a span of the last 2 million years (Ryan et al., 2003). One such obvious example of colonization waves is the significantly diverged haplotypes in the rivers of the Crimean Peninsula. Crimean haplotypes were detected circum Black Sea in Bulgarian and Turkish rivers as well as in rivers of Russian coast of the Black Sea, from Sochi to Tuapse. The possibly mixed haplotypes in Crimea reflect the complicated history of the Crimean rivers, which changed their directions and mouth position significantly. For example, the longest Crimean river, the Salgir, is a type locality for B. tauricus and has several ancient channels (Sludskiy, 1953). The most distant mouths of these channels are separated by $>800 \mathrm{~km}$ along the modern coastline. It might be important for the settlement of different migrating groups brought by different lacustrine currents. We have no data on the direction of the currents in ancient freshwater Black Sea. Nevertheless, the Crimean Peninsula, being largely beaked into the Black Sea and having a prolonged coastal line, could serve as a significant 'trap' for collecting barbels that migrate from both western or eastern parts of the giant freshwater lake.

Another example of several waves of migrations is the presence of two different haplogroups of B. escherichii in the northeastern part of the Black Sea basin. The B. escherichii individuals detected in the Kuban basin had the same haplotypes as conspecific population from 
Turkey near Rize (distance is ca. $620 \mathrm{~km}$ along the coastline) and shared no haplotypes with closely located populations from the Black Sea rivers of the Russian Coast (ca. $120 \mathrm{~km}$ distance). This Kuban population of $B$. escherichii may be considered a relict population, as a remnant of the previous wave of colonization in the riverine system where the endemic barbel B. kubanicus strongly predominates.

Here, we agree with suggestions that such a phylogeographical pattern most likely reflects the allopatric divergence of multiple ancestral populations (Kotlík et al., 2004) with subsequent contacts and, supposedly, hybridization and gene flow. In addition, the Azov-Black Sea is considered to be one of important glacial refugia for many freshwater fish species, such as the chub Squalius cephalus (Durand et al., 1999), the perch Perca fluviatilis (Nesbø et al., 1999), the brown trout Salmo trutta (Bernatchez, 2001; Bernatchez and Osinov, 1995), roaches Rutilus (Kotlík et al., 2008; Levin et al., 2017), and including Circum Black Sea barbels (Kotlík et al., 2004). During some periods usually associated with glaciation periods, when the level of Ocean dropped, the Black Sea level was lower by 100 (150) m (Yanina, 2014) and became a freshwater lake with a surface half of its current size. The last freshwater phase of the Black Sea terminated approximately 7150 years BP (Ryan et al., 1997). Despite the Black and Caspian Seas connecting several times during the Late Pleistocene sub-epoch via the Manych depression, no haplotypes of the Black Sea lineages were detected in the Caspian Sea basin.

We suggest that shallower divergence between members of the Black Sea group of species compared to such in the Caspian group is due to multiple repeated contacts between isolated lineages and sub-isolated populations during freshwater phases of the Black Sea water body. Therefore, glaciation-deglaciation cycles have influenced the dispersal of circum Black Sea populations and could significantly upset speciation and divergence via a homogenizing effect on genetic structure. At the same time, an example of B. rionicus, with a well-diversified population structure in both mtDNA and nDNA loci that is well diverged from other Black Sea 
lineages and is geographically well restricted, provides evidence for local refugium probably existing for a long time during climatic oscillations.

\subsection{Taxonomical implications and distributional notes}

The most obvious taxonomic outputs of the present study are validation of the Rioni barbel $B$. rionicus and synonymization of the Sevan barbel B. goktschaicus with Kura barbel B. cyri. We confirmed revalidation that the Barbus rionicus was widely distributed in Western Transcaucasia, as inferred from our genetic data. The range of this species includes the Transcaucasian rivers from the Choruh basin northward to the Bzyb River, i.e., approximately $260 \mathrm{~km}$ along the Black Sea coast. Nevertheless, the northern range boundary of B. rionicus is permeable for the adjacent northern species, B. escherichii (loc. 42 in Fig. 1). Another species, $B$. artvinica, was described from the Choruh basin with $B$. rionicus simultaneously in the same book by Kamensky (1899); however, the Choruh population is genetically identical to other populations of $B$. rionicus. Therefore, both names are valid for the selection of only one of them, according to the International Code of Zoological Nomenclature (http://iczn.org/code). We accept the B. rionicus name as it has already been used (Bayçelebi et al., 2015).

No divergence between B. goktschaicus and B. cyri was detected by all studied markers. The Lake Sevan with tributaries being a range for B. goktschaicus was recently formed and isolated from the Araks basin approximately 20000 years ago by the formation of an unpassable Varser waterfall on the Hrazdan R., which is the single outlet of Lake Sevan (Milanovskiy, 1957; Sarkissyan, 1962). Based on phenotypic data, Dadikyan (1986) recognized Sevan barbel as subspecies of the Kura barbel. At the same time, the Sevan population system is unique and composed of three sympatric forms (Chikova, 1955) under threat and protected by the list of the Red Data book of the Armenian Republic (Aghasyan and Kalashyan, 2010). 
Our sampling covered type localities or type basins in the Kura system for some taxa that were described by Kamensky (1899), particularly B. bortschalinicus (loc. 23 in Fig. 1) and B. toporovanicus (loc. 19, 29 in Fig. 1). They were synonymized with B. cyri by Berg (1914). Our genetic data confirmed their identity with B. cyri.

The Crimean barbel B. tauricus was described from the Salgir R. by Kessler (1877). The Crimean populations are genetically heterogeneous and are similar to some populations of $B$. escherichii Steindachner, 1897, which are distributed around the Black Sea. The B. tauricus / escherichii complex of populations have a complicated history of migrations, re-colonizations of rivers discharged to Black Sea, and gene flow between lineages and populations (see Kotlík et al., 2004 and the present study). Another species, B. oligolepis Battalgil, 1941, which is known to be from the Marmara Sea basin, also belongs to the B. tauricus / escherichii complex, as inferred from the COI phylogeny (Fig. S1). At the same time, a couple of samples from the southern coast of the Black Sea, which were previously assigned as B. escherichii, are well diverged compared to other samples and might represent a different species (noted as Barbus sp. in the present study). Noticeably, there is another species complex, Barbus petenyi Heckel, 1852, among the barbels inhabiting the Danube basin, which also belonged to the Black Sea drainage (Antal et al., 2016; Kotlík et al., 2002; Žutinić et al., 2014).

\section{Acknowledgments}

We are very thankful to O. Artaev, D. Karabanov, M. Matvejew, D. Palatov, A. Prokin, M. Saprykin, I. Turbanov, and A. Yakimov for their help in the field as well as to N. Bogutskaya for consultation on the taxonomy. The study was supported by Russian Science Foundation (grant no. 15-14-10020). 


\section{References}

Abdurakhmanov, Yu.A., 1962. Freshwater fishes of Azerbaijan. Izd-vo Akademii nauk Azerbaidzhanskoǐ SSR, Baku.

Abraham, M., 1996. The spermatogenetic process in Barbus longiceps, Capoeta damascina and their natural sterile hybrid (Teleostei, Cyprinidae). J. Fish Biol. 49, 458-468.

Aghasyan, A.L., Kalashyan M.Y., 2010. The Red Data Book of the Animals of the Republic of Armenia. Zangak Press, Yerevan.

Aljanabi, S.M., Martinez, I., 1997. Universal and rapid salt-extraction of high quality genomic DNA for PCR-based techniques. Nucleic Acids Res. 25, 4692-4693.

Antal, L., László, B., Kotlík, P., Mozsár, A., Czeglédi, I., Oldal, M., Kemenesi, G., Jakab, F., Nagy, S.A., 2016. Phylogenetic evidence for a new species of Barbus in the Danube River basin. Mol. Phylogen. Evol. 96, 187-194.

Bandelt, H.J., Forster, P., Röhl, A., 1999. Median-joining networks for inferring intraspecific phylogenies. Mol. Biol. Evol. 16, 37-48.

Bayçelebi, E., Turan, D., Japoshvili, B., 2015. Fish fauna of Çoruh River and two first record for Turkey. Turk. J. Fish. Aquat. Sci. 15, 783-794.

Berg, L.S., 1914. Fishes. Vol. 3, Ostariophysi, Part. 2. Izdatelstvo Imperatorskoi Akademii Nauk, St. Petersburg (in Russian).

Bernatchez, L., 2001. The evolutionary history of brown trout (Salmo trutta L.) inferred from phylogeographic, nested clade, and mismatch analyses of mitochondrial DNA variation. Evol. 55, 351-379.

Bernatchez, L., Osinov, A., 1995. Genetic diversity of trout (genus Salmo) from its most eastern native range based on mitochondrial DNA and nuclear gene variation. Mol. Ecol. 4, 285-298. 
Berrebi, P., Tsigenopoulos, C.S., 2003. Phylogenetic organization of the genus Barbus sensu stricto: a review based on data obtained using molecular markers, in: Bănărescu P., Bogutskaya N.G. (Eds.), The Freshwater Fishes of Europe, 5/II: Cyprinidae 2/II. AULA-Verlag, Wiesbaden, pp. 11-22.

Berrebi, P., Cattaneo-Berrebi, G., Le Brun, N., 1993. Natural hybridization of two species of tetraploid barbels: Barbus meridionalis and Barbus barbus (Osteichtyes, Cyprinidae) in southern France. Biological J. Linn. Soc. 48, 319-333.

Bogutskaya, N.G., 2003a. Barbus ciscaucasicus, in: Bănărescu P., Bogutskaya N.G. (Eds.), The Freshwater Fishes of Europe, 5/II: Cyprinidae 2/II. AULA-Verlag, Wiesbaden, pp. 163-172.

Bogutskaya, N.G., 2003b. Barbus lacerta, in: Bănărescu P., Bogutskaya N.G. (Eds.), The Freshwater Fishes of Europe, 5/II: Cyprinidae 2/II. AULA-Verlag, Wiesbaden, pp. 251-270.

Bogutskaya, N.G., 2003c. Barbus goktschaicus, in: Bănărescu P., Bogutskaya N.G. (Eds.), The Freshwater Fishes of Europe, 5/II: Cyprinidae 2/II. AULA-Verlag, Wiesbaden, pp. 207-218.

Böhme, M., Ilg, A., 2003. fosFARbase. http://www.wahrestaerke.com/ (Accessed 31.08.2016)

Buonerba, L., Zaccara, S., Delmastro, G.B., Lorenzoni, M., Salzburger, W., Gante, H.F., 2015. Intrinsic and extrinsic factors act at different spatial and temporal scales to shape population structure, distribution and speciation in Italian Barbus (Osteichthyes: Cyprinidae). Mol. Phylogenet. Evol. 89, 115-129.

Chenuil, A., Galtier, N., Berrebi, P., 1999. A test of the hypothesis of an autopolyploid vs. allopolyploid origin for a tetraploid lineage: application to the genus Barbus (Cyprinidae). Heredity. 82, 373-380.

Chikova, V.M., 1955. Sevan barbel Barbus goktschaicus Kessler (systematics, biology, and fishery), in: Markosian, A.K. (Ed.), Proceedings of Sevan Hydrobiological Station. 14, 121-163 (in Russian). 
Çiçek, E., Birecikligil, S.S., Fricke, R., 2016. Addenda and errata of: Freshwater fishes of Turkey: a revised and updated annotated checklist. FishTaxa. 1, 116-117.

Clement, M., Posada, D., Crandall, K.A., 2000. TCS: a computer program to estimate gene genealogies. Mol. Ecol. 9, 1657-1659.

Crespin, L., Berrebi, P., Lebreton, J.D., 1999. Asymmetrical introgression in a freshwater fish hybrid zone as revealed by a morphological index of hybridization. Biol. J. Linn. Soc. 67, 57-72.

Dadikyan, M.G., 1986. Fishes of Armenia. AN Arm. SSR, Erevan (in Russian).

Doadrio, I., 1990. Phylogenetic relationships and classification of western palaearctic species of the genus Barbus (Osteichthyes, Cyprinidae). Aquat. Living Resour. 3, 265-282.

Doadrio, I., Carmona, J.A., Machordom, A., 2002. Haplotype diversity and phylogenetic relationships among the Iberian barbels (Barbus, Cyprinidae) reveal two evolutionary lineages. J. Hered. 93, 140-147.

Doadrio, I., Casado, P., 1989. Nota sobre la ictiofauna continental de los yacimientos de la cuenca de Guadix-Baza (Granada), in: Alberdi, A.T., Bonadonna, F.P. (Eds.), Geologia y Paleontologia de la cuenca de Guadix-Baza. Trabajos sobre el Neogeno Cuaternario, Museo National de Ciencias Naturales (CSIC), Madrid, pp. 139-150.

Drummond, A.J., Ho, S.Y.W., Phillips, M.J., Rambaut, A., 2006. Relaxed phylogenetics and dating with confidence. PLoS Biol. 4, 699-710.

Drummond, A.J., Suchard, M.A., Xie, D., Rambaut, A., 2012. Bayesian phylogenetics with BEAUti and the BEAST 1.7. Mol. Biol. Evol. 29, 1969-1973.

Durand, J.D., Persat, H., Bouvet, Y., 1999. Phylogeography and postglacial dispersion of the chub (Leuciscus cephalus) in Europe. Mol. Ecol. 8, 989-997. 
Durand, J.D., Tsigenopoulos, C.S., Ünlü, E., Berrebi, P., 2002. Phylogeny and biogeography of the family Cyprinidae in the Middle East inferred from cytochrome $b$ DNA - evolutionary significance of this region. Mol. Phylogenet. Evol. 22, 91-100.

Edgar, R.C., 2004. MUSCLE: multiple sequence alignment with high accuracy and high throughput. Nucleic Acids Res. 32, 1792-1797.

Eschmeyer, W. N., Fricke, R., van der Laan, R., 2017. Catalog of Fishes. San Francisco, CA (California Academy of Sciences). https://calacademy.org/scientists/projects/catalog-of-fishes (accessed 15 August 2017)

Esin, N.V., Yanko-Hombach, V.V., Esin, N.I., 2016. Evolutionary mechanisms of the Paratethys Sea and its separation into the Black Sea and Caspian Sea. Quat. Int. 465, 46-53.

Flot, J.F., Tillier, A., Samadi, S., Tillier, S., 2006. Phase determination from direct sequencing of length-variable DNA regions. Mol. Ecol. Resour. 6, 627-630.

Gandlin, A.A., Mustafaev, N.D., Yakimov, A.V., Levin, B.A., 2017. Updating the geographical range of Terek barbel Barbus ciscaucasicus Kessler, 1877 (Cyprinidae) using the cytochrome b molecular marker. Inland Water Biol. 10, 115-119.

Gante, H.F., Doadrio, I., Alves, M.J., Dowling, T.E., 2015. Semi-permeable species boundaries in Iberian barbels (Barbus and Luciobarbus, Cyprinidae). BMC Evol. Biol. 15, 111.

Gante, H.F., Micael, J., Oliva-Paterna, F.J., Doadrio, I., Dowling, T.E., Alves, M.J., 2009. Diversification within glacial refugia: tempo and mode of evolution of the polytypic fish Barbus sclateri. Mol. Ecol. 18, 3240-3255.

García-Alix, A., Minwer-Barakat, R., Suárez, E.M., Freudenthal, M., Martín, J.M., 2008. Late Miocene-Early Pliocene climatic evolution of the Granada Basin (southern Spain) deduced from the paleoecology of the micromammal associations. Palaeogeogr. Palaeoclimatol. Palaeoecol. 265, 214-225. 
Geiger, M.F., Herder, F., Monaghan, M.T., Almada, V., Barbieri, R., Bariche, M., Berrebi, P.,

Bohlen, J., Casal-Lopez, M., ..., Freyhof, J., 2014. Spatial heterogeneity in the Mediterranean Biodiversity Hotspot affects barcoding accuracy of its freshwater fishes. Mol. Ecol. Resour. 14, $1210-1221$.

Ghanavi, H.R., Gonzalez, E.G., Doadrio, I., 2016. Phylogenetic relationships of freshwater fishes of the genus Capoeta (Actinopterygii, Cyprinidae) in Iran. Ecol. Evol. 6, 8205-8222.

Gorshkova, G., Gorshkov, S., Golani, D., 2002. Karyotypes of Barbus canis and Capoeta damascina (Pisces, Cyprinidae) from the Middle East. Ital. J. Zool. 69, 191-194.

Gouy, M., Guindon, S., Gascuel, O., 2009. SeaView version 4: a multiplatform graphical user interface for sequence alignment and phylogenetic tree building. Mol. Biol. Evol. 27, 221-224.

Helaers, R., Milinkovitch, M.C., 2010. MetaPIGA v2. 0: maximum likelihood large phylogeny estimation using the metapopulation genetic algorithm and other stochastic heuristics. BMC Bioinformatics. 11, 379.

International Code of Zoological Nomenclature http://iczn.org/code (accessed 10 August 2017) Ivanova N.V., Zemlak T.S., Hanner R.H., Hebert P.D., 2007. Universal primer cocktails for fish DNA barcoding. Mol. Ecol. Resour. 7, 544-548.

Jolivet, L., Faccenna, C., 2000. Mediterranean extension and the Africa-Eurasia collision. Tectonics. 19, 1095-1106.

Kalyaanamoorthy, S., Minh, B.Q., Wong, T.K.F., von Haeseler, A., Jermiin, L.S., 2017. ModelFinder: fast model selection for accurate phylogenetic estimates. Nat. Methods. 14, 587.

Kamensky, S.N., 1899. Die Cypriniden der Kaukasusländer und Ihrer angrenzenden Meere. Tiflis. (In Russian, German summary). 
Kessler, K.F., 1877. The Aralo-Caspian Expedition. IV. Fishes of the Aralo-Caspio-Pontine ichthyological region. Naturgeschichte der Fische Islands, St. Petersburg (Supplement to: Trudy St. Petersburg. Obsh. Estestv.).

Khaefi, R., Esmaeili, H.R., Geiger, M.F., Eagderi, S., 2017. Taxonomic review of the cryptic Barbus lacerta species group with description of a new species (Teleostei: Cyprinidae). FishTaxa. 2, 90-115.

Kotlík, P., Berrebi, P., 2001. Phylogeography of the barbel (Barbus barbus) assessed by mitochondrial DNA variation. Mol. Ecol. 10, 2177-2185.

Kotlík, P., Berrebi, P., 2002. Genetic subdivision and biogeography of the Danubian rheophilic barb Barbus petenyi inferred from phylogenetic analysis of mitochondrial DNA variation. Mol. Phylogenet. Evol. 24, 10-18.

Kotlík, P., Bogutskaya, N.G., Ekmekci, F.G., 2004. Circum Black Sea phylogeography of Barbus freshwater fishes: divergence in the Pontic glacial refugium. Mol. Ecol. 13, 87-95.

Kotlík, P., Markova, S., Choleva, L., Bogutskaya, N.G., Ekmekci, F.G., Ivanova, P.P., 2008. Divergence with gene flow between Ponto-Caspian refugia in an anadromous cyprinid Rutilus frisii revealed by multiple gene phylogeography. Mol. Ecol. 17, 1076-1088.

Kotlík, P., Tsigenopoulos, C S., Rab, P., Berrebi, P., 2002. Two new Barbus species from the Danube River basin, with redescription of B. petenyi (Teleostei: Cyprinidae). Folia Zool. 51, $227-240$.

Krysanov, E., 1999. Karyotypes of Varicorhinus capoeta and Barbus goktschaicus (Cypriniformes) from lake Sevan, Armenia. J. Ichthyol. 39, 187-189.

Lajbner, Z., Šlechtová, V., Šlechta, V., Švátora, M., Berrebi, P., Kotlík, P., 2009. Rare and asymmetrical hybridization of the endemic Barbus carpathicus with its widespread congener Barbus barbus. J. Fish Biol. 74, 418-436. 
Lanfear, R., Calcott, B., Ho, S.Y.W., Guindon, S., 2012. PartitionFinder: combined selection of partitioning schemes and substitution models for phylogenetic analyses. Mol. Biol. Evol. 29, $1695-1701$.

Lazukov, G.I., 1989. The Pleistocene of the USSR's Territory. Vysshaya Shkola, Moscow.

Leigh, J.W., Bryant, D., 2015. Popart: full-feature software for haplotype network construction. Methods Ecol. Evol. 6, 1110-1116.

Levin, B. A., Freyhof, J., Lajbner, Z., Perea, S., Abdoli, A., Gaffaroğlu, M., Özuluğ, M., Rubenyan, H.R., Salnikov, V.B., Doadrio, I., 2012. Phylogenetic relationships of the algae scraping cyprinid genus Capoeta (Teleostei: Cyprinidae). Mol. Phylogenet. Evol. 62, 542-549.

Levin, B.A., 2004. Phenetic relationships of barbels of the Caucasian region and their status in the system of the genus Barbus sensu stricto (Cyprinidae). J. Ichthyol. 44, 444-449.

Levin, B.A., Rubenyan, H.R., 2006. Threatened fishes of the world: Barbus goktschaicus Kessler, 1877 (Cyprinidae). Env. Biol. Fish. 76, 409-410.

Levin, B.A., Simonov, E., Matveyev, M.P., Artaev, O.N., Mustafayev, N.J., Pashkov, A.N., Roubenyan, H.R., 2018. DNA barcoding of the fishes of the genus Alburnoides (Actinopterygii, Cyprinidae) from Caucasus. Mitochondrial DNA Pt A. 29, 49-55.

Levin, B.A., Simonov, E.P., Ermakov, O.A., Levina, M.A., Interesova, E.A., Kovalchuk, O.M, Malinina, Y.A., Mamilov, N.S., Mustafayev, ..., Vekhov, D.A., 2017. Phylogeny and phylogeography of the roaches, genus Rutilus (Cyprinidae), at the Eastern part of its range as inferred from mtDNA analysis. Hydrobiol. 788, 33-46.

Librado, P., Rozas, J., 2009. DnaSP v5: a software for comprehensive analysis of DNA polymorphism data. Bioinformatics. 25, 1451-1452. 
Machordom, A., Berrebi, P., Doadrio, I., 1990. Spanish barbel hybridization detected using enzymatic markers: Barbus meridionalis Risso $\times$ Barbus haasi Mertens (Osteichthyes, Cyprinidae). Aquat. Living Resour. 3, 295-303.

Machordom, A., Doadrio, I., 2001. Evolutionary history and speciation modes in the cyprinid genus Barbus. Proc. R. Soc. London B Biol. Sci. 268, 1297-1306.

Marková, S., Šanda, R., Crivelli, A., Shumka, S., Wilson, I. F., Vukić, J., Berrebi, P., Kotlík, P., 2010. Nuclear and mitochondrial DNA sequence data reveal the evolutionary history of Barbus (Cyprinidae) in the ancient lake systems of the Balkans. Mol. Phylogenet. Evol. 55, 488-500.

Maruashvili, L., 1981. Physical Geography of the Caucasus. Metsniereba, Tbilisi. (in Georgian).

Meraner, A., Venturi, A., Ficetola, G.F., Rossi, S., Candiotto, A., Gandolfi, A., 2013. Massive invasion of exotic Barbus barbus and introgressive hybridization with endemic Barbus plebejus in Northern Italy: where, how and why? Mol. Ecol. 22, 5295-5312.

Milanovskiy, E.E., 1957. History of formation of Sevan depression in light of knowledge about neotectonics of Lesser Caucasus. Proceedings of IV Geomorphological Conference on Studying Caucasus and Transcaucasia. Yerevan, 120-146 (in Russian).

Minh, B.Q., Nguyen, M.A.T., von Haeseler, A., 2013. Ultrafast approximation for phylogenetic bootstrap. Mol. Biol. Evol. 30, 1188-1195.

Myers, N., Mittermeier, R.A., Mittermeier, C.G., Da Fonseca, G.A., Kent, J., 2000. Biodiversity hotspots for conservation priorities. Nature. 403, 853.

Naseka, A.M., 2010. Zoogeographical freshwater divisions of the Caucasus as a part of the West Asian transitional region. Proc. Zool. Inst. RAS. 314, 469-492.

Nesbø, C.L., Fossheim, T., Vøllestad, L.A., Jakobsen, K.S., 1999. Genetic divergence and phylogeographic relationships among European perch (Perca fluviatilis) populations reflect glacial refugia and postglacial colonization. Mol. Ecol. 8, 1387-1404. 
Nguyen, L.T., Schmidt, H.A., von Haeseler, A., Minh, B.Q., 2014. IQ-TREE: a fast and effective stochastic algorithm for estimating maximum-likelihood phylogenies. Mol. Biol. Evol. 32, 268274.

Oikonomou, A., Leprieur, F., Leonardos, I.D., 2014. Biogeography of freshwater fishes of the Balkan Peninsula. Hydrobiol. 738, 205-220.

Palumbi, S.R., 1996. Nucleic acids II: the polymerase chain reaction, in: Hillis, D.M., Moritz, C., Mable, B.K. (Eds.), Molecular Systematics. Sinauer Associates, Sunderland, MA, pp. 205-247.

Paradis, E., Claude, J., Strimmer, K., 2004. APE: analyses of phylogenetics and evolution in R language. Bioinformatics. 20, 289-290.

Perdices, A., Bermingham, E., Montilla, A., Doadrio, I., 2002. Evolutionary history of the genus Rhamdia (Teleostei: Pimelodidae) in Central America. Mol. Phylogenet. Evol. 25, 172-189.

Por, F.D., Dimentman, Ch., 1989. The legacy of Tethys: an aquatic biogeography of the Levant. Monographiae Biologicae, Kluwer, Dordrecht.

Poznyak, V.G., 1987. The Fauna of Kalmykia. Fishes. Kalmytskoye Knizhnoye Izdatelstvo, Elista.

Ráb, P., Collares-Pereira, M.J., 1995. Chromosomes of European cyprinid fishes (Cyprinidae, Cypriniformes). Folia Zool. 44, 193-214.

Rambaut, A., Drummond, A., 2008. FigTree: Tree figure drawing tool, version 1.2. 2. Institute of Evolutionary Biology, University of Edinburgh.

Rambaut, A., Drummond, A.J., 2013. TreeAnnotator v1. 7.0. Available as part of the BEAST package at http://beast.bio.ed.ac.uk/ (accessed 1 August 2017). 
Rambaut, A., Suchard, M.A., Xie, D., Drummond, A.J., 2014. Tracer v1. 6 Computer Program and Documentation Distributed by the Author. http://beast.bio.ed.ac.uk/Tracer (accessed 3 August 2017).

Reshetnikov, Y.S., Popova, O.A., Sokolov, L.I., Tsepkin, E.A., Sideleva, V.G., Dorofeeva, E.A., ... Korolev, V.V., 2003. Atlas of Russian Freshwater Fishes. V. 1. Nauka, Moscow (in Russian).

Ryan, W.B., Major, C.O., Lericolais, G., Goldstein, S.L., 2003. Catastrophic flooding of the Black Sea. Annu. Rev. Earth Planet. Sci. 31, 525-554.

Ryan, W.B.F., Pitman III, W.C., Major, C.O., Shimkus, K., Moskalenko, V., Jones, G.A., Dimitrov P., Gorür, N., Sakinç, M., Yüce, H., 1997. An abrupt drowning of the Black Sea shelf. Marine Geol. 138, 119-126.

Sanderson, M.J., 2002. Estimating absolute rates of molecular evolution and divergence times: a penalized likelihood approach. Mol. Biol. Evol. 19, 101-109.

Sarkissyan, S.G., 1962. Petrographic and mineralogical investigation of Lake Sevan basin. Izdatel'stvo AN ArmSSR, Yerevan. (in Russian).

Sludskiy, A.F., 1953. Ancient valleys of the Salgir River. Bulletin of Crimean branch of Geographical Society of USSR. Crimean branch of Academy of Sciences of USSR, Simferopol.

Sousa-Santos, C., Robalo, J.I., Collares-Pereira, M.J., Almada, V.C., 2005. Heterozygous indels as useful tools in the reconstruction of DNA sequences and in the assessment of ploidy level and genomic constitution of hybrid organisms. DNA Sequence. 16, 462-467.

Stephens, M., Donnelly, P., 2003. A comparison of Bayesian methods for haplotype reconstruction from population genotype data. Am. J. Hum. Genet. 73, 1162-1169.

Stephens, M., Smith, N.J., Donnelly, P., 2001. A new statistical method for haplotype reconstruction from population data. Am. J. Hum. Genet. 68, 978-989. 
Stoumboudi, M.T., Abraham, M., Villwock, W., Ben-Tuvia, A., Economidis, P.S., Shapiro, J., 1992. Gonad development and somatic growth in an intergeneric cyprinid hybrid from Lake Kinneret, Israel. J. Appl. Ichthyol. 8, 110-121.

Stoumboudi, M.T., Villwock, W., Sela, J., Abraham, M., 1993. Gonadosomatic index in Barbus longiceps, Capoeta damascina and their natural hybrid (Pisces, Cyprinidae), versus spermatozoan index in the parental males. J. Fish Biol. 43, 865-875.

Tsigenopoulos, C.S., Durand, J.D., Ünlü, E., Berrebi, P., 2003. Rapid radiation of the Mediterranean Luciobarbus species (Cyprinidae) after the Messinian salinity crisis of the Mediterranean Sea, inferred from mitochondrial phylogenetic analysis. Biol. J. Linn. Soc. 80, $207-222$.

Tsigenopoulos, C.S., Karakousis, Y., Berrebi, P., 1999. The North Mediterranean Barbus lineage: phylogenetic hypotheses and taxonomic implications based on allozyme data. J. Fish Biol. 54, 267-286.

Tsigenopoulos, C.S., Kotlík, P., Berrebi, P., 2002. Biogeography and pattern of gene flow among Barbus species (Teleostei: Cyprinidae) inhabiting the Italian Peninsula and neighbouring Adriatic drainages as revealed by allozyme and mitochondrial sequence data. Biol. J. Linn. Soc. 75, 83-99.

Tsoumani, M., Georgiadis, A., Giantsis, I.A., Leonardos, I., Apostolidis, A.P., 2014. Phylogenetic relationships among Southern Balkan Rutilus species inferred from cytochrome $b$ sequence analysis: Micro-geographic resolution and taxonomic implications. Biochem. Systemat. Ecol. 54, 172-178.

Vasiliev, V.P., 1985. Evolutionary karyology of fishes. Nauka, Moscow (in Russian). 
Yang, L., Sado, T., Hirt, M.V., Pasco-Viel, E., Arunachalam, M., Li, J., Wang, X., Freyhof, J., Saitoh, K., ..., Mayden, R.L., 2015. Phylogeny and polyploidy: resolving the classification of cyprinine fishes (Teleostei: Cypriniformes). Mol. Phylogenet. Evol. 85, 97-116.

Yanina, T.A., 2014. The Ponto-Caspian region: environmental consequences of climate change during the Late Pleistocene. Quat. Int. 345, 88-99.

Zakšek, V., Sket, B., Trontelj, P., 2007. Phylogeny of the cave shrimp Troglocaris: evidence of a young connection between Balkans and Caucasus. Mol. Phylogenet. Evol. 42, 223-235.

Zardoya, R., Doadrio, I., 1999. Molecular evidence on the evolutionary and biogeographical patterns of European cyprinids. J. Mol. Evol. 49, 227-237.

Zardoya, R., Economidis, P.S., Doadrio, I., 1999. Phylogenetic relationships of Greek Cyprinidae: molecular evidence for at least two origins of the Greek cyprinid fauna. Mol. Phylogenet. Evol. 13, 122-131.

Žutinić, P., Jelić, D., Jelić, M., Buj, I., 2014. A contribution to understanding the ecology of the large spot barbel-sexual dimorphism, growth and population structure of Barbus balcanicus (Actinopterygii; Cyprinidae) in Central Croatia. North-West J. Zool. 10, 158-166. 
Table 1. Markers used and primer sequences.

\begin{tabular}{|c|c|c|}
\hline Marker & Primer & Reference \\
\hline $\begin{array}{l}\text { COI } \\
(626 \mathrm{bp})\end{array}$ & $\begin{array}{l}\text { M13 tailed primer cocktail: } \\
\text { FishF2_t1: 5'-TGT AAA ACG ACG GCC AGT CGA } \\
\text { CTA ATC ATA AAG ATA TCG GCA C-3' } \\
\text { FishR2_t1: 5'-CAG GAA ACA GCT ATG ACA CTT } \\
\text { CAG GGT GAC CGA AGA ATC AGA A-3' } \\
\text { VF2_t1: 5'-TGT A AA ACG ACG GCC AGT CAA CCA } \\
\text { ACC ACA AAG ACA TTG GCA C-3' } \\
\text { FR1d_t1: 5'-CAG GAA ACA GCT ATG ACA CCT CAG } \\
\text { GGT GTC CGA ARA AYC ARA A-3' }\end{array}$ & $\begin{array}{l}\text { Ivanova et al. } \\
2007\end{array}$ \\
\hline $\begin{array}{l}\text { Cytb } \\
(993 \mathrm{bp})\end{array}$ & $\begin{array}{l}\text { GluDg: 5'-TGA CTT GAA RAA CCA YCG TTG-3' } \\
\text { H16460: 5'-CGA YCT TCG GAT TAA CAA GAC CG-3' } \\
\text { GluF: 5'-AAC CAC CGT TGT ATT CAA CTA CAA-3' } \\
\text { ThrR: 5'-ACC TCC GAT CTT CGG ATT ACA AGA } \\
\text { CCG-3' }\end{array}$ & $\begin{array}{l}\text { Palumbi, 1996; } \\
\text { Perdices et al., } \\
\text { 2002; } \\
\text { Machordom \& } \\
\text { Doadrio, } 2001\end{array}$ \\
\hline $\begin{array}{l}\text { Act-2 } \\
(496 \mathrm{bp})\end{array}$ & $\begin{array}{l}\text { Act18U21: 5'-GCT CCA GAA AAA CCT ATA AGT-3' } \\
\text { Act554L21: 5'-CTC ACT GAA GCT CCT CTT AAC-3' }\end{array}$ & $\begin{array}{l}\text { Marková et al., } \\
2010\end{array}$ \\
\hline
\end{tabular}


Table 2. The best partition schemes.

\begin{tabular}{|l|l|l|l|l|}
\hline Partitions & Cytb & COI & \multicolumn{2}{|c|}{ Concatenated Cytb+COI } \\
\hline \multicolumn{5}{|c|}{ ML } \\
\hline 1 Pos. & TN+I+G & TIM+I+G & $C y t b:$ TIM2+G & COI: HKY+I \\
\hline 2 Pos. & TN+I+G & TIM+I+G & $C y t b:$ HKY+I & COI: HKY+I \\
\hline 3 Pos. & TN+I+G & TIM+I+G & Cytb: HKY+I & COI: TIM2+G \\
\hline & & & BI & COI: K80+I+G \\
\hline 1 Pos. & K80+I+G & K80+I+G & Cytb: HKY & COI: HKY \\
\hline 2 Pos. & HKY+G & F81+I & $C y t b:$ K80+I+G & COI: GTR+G \\
\hline 3 Pos. & GTR+G & GTR+G & $C y t b:$ GTR+G & \\
\hline
\end{tabular}


bioRxiv preprint doi: https://doi.org/10.1101/473173; this version posted November 19, 2018. The copyright holder for this preprint (which was not certified by peer review) is the author/funder, who has granted bioRxiv a license to display the preprint in perpetuity. It is made available under aCC-BY-NC-ND 4.0 International license. 
Table 3. Intraspecific genetic variation of Barbus spp. from Caucasus region and Crimean Peninsula in Cytb sequences. n/N - sample size/number of haplotypes; $h \pm \mathrm{SD}$ - haplotype diversity \pm standard deviation; $\pi \pm \mathrm{SD}$ - nucleotide diversity (per site) \pm standard deviation; K - average number of nucleotide differences; Mean intra-sp \pm SE - mean intraspecies p-distance \pm standard error; Max intra-sp - maximum intraspecies p-distance; Distance to $\mathrm{NS} \pm \mathrm{SE}-$ mean p-distance to a nearest species \pm standard error (based on 1000 bootstrap replications).

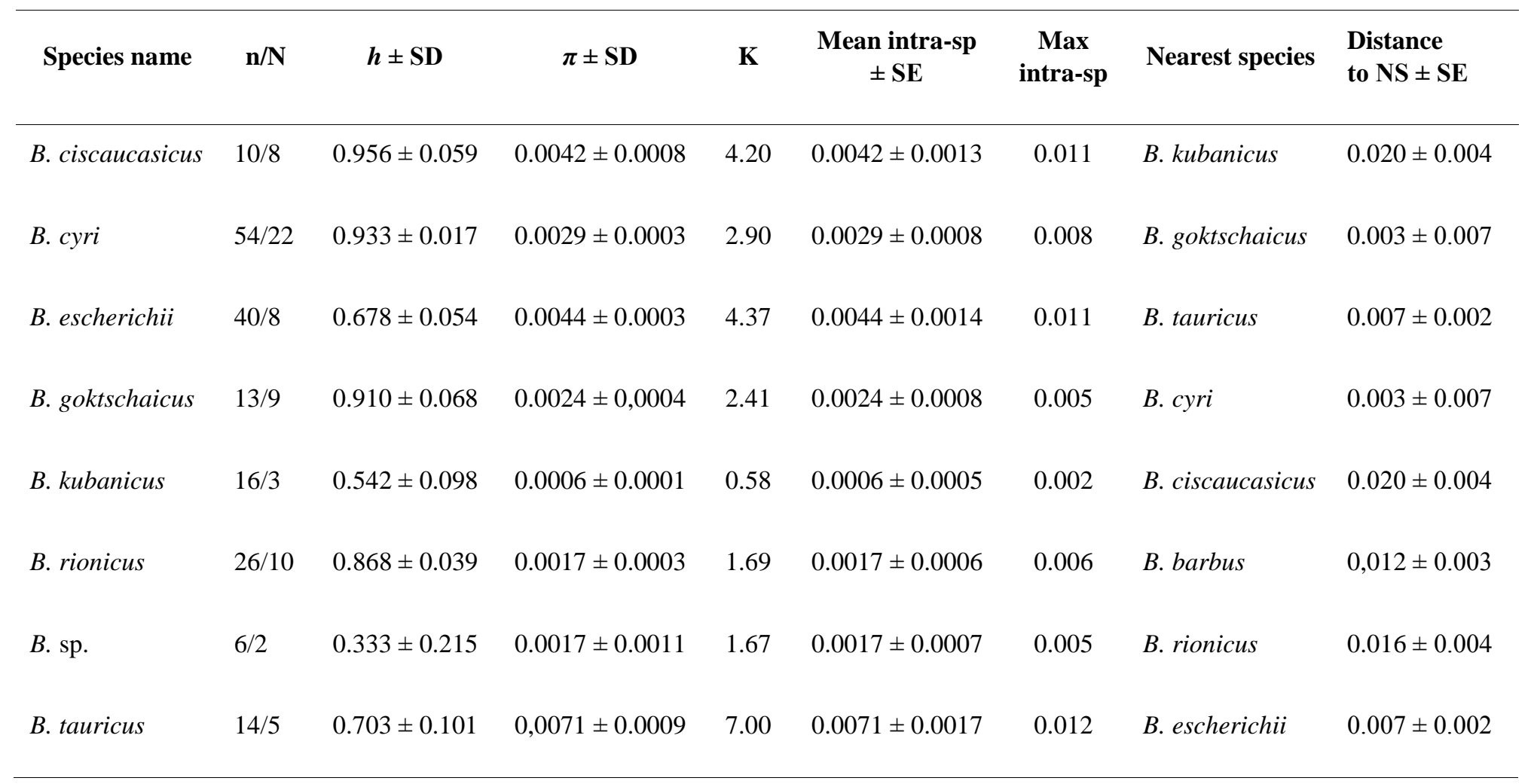



Table 4. Intraspecific genetic variation of Caucasian barbels in nuclear marker Act-2.

\begin{tabular}{|c|c|c|c|c|c|c|c|c|}
\hline Species & $\begin{array}{l}\text { No. } \\
\text { individuals } \\
\text { (haplotypes) }\end{array}$ & $\begin{array}{l}\text { Length, } \\
\text { bp }\end{array}$ & $\mathbf{h}^{*}$ & $\mathbf{H d} \pm \mathbf{S D}^{*}$ & $\pi \pm \mathbf{S D}$ & $\mathbf{S}$ & $\mathbf{k}$ & InDels \\
\hline B. ciscaucasicus & $7(14)$ & 443 & 2 & $0.143 \pm 0.119$ & $\begin{array}{l}0.00064 \pm \\
0.00054\end{array}$ & 2 & 0.29 & 0 \\
\hline B. cyri & $8(16)$ & $440-447$ & 4 & $0.350 \pm 0.148$ & $\begin{array}{l}0.00108 \pm \\
0.00050\end{array}$ & 2 & 0.47 & 1 \\
\hline B. escherichii & $17(34)$ & $434-447$ & 5 & $0.747 \pm 0.035$ & $\begin{array}{l}0.00588 \pm \\
0.00083\end{array}$ & 9 & 2.53 & 2 \\
\hline B. goktschaicus & $5(10)$ & $440-447$ & 3 & $0.622 \pm 0.138$ & $\begin{array}{l}0.00081 \pm \\
0.00036\end{array}$ & 1 & 0.36 & 1 \\
\hline B. kubanicus & $8(16)$ & 443 & 2 & $0.125 \pm 0.106$ & $\begin{array}{l}0.00028 \pm \\
0.00024\end{array}$ & 1 & 0.13 & 0 \\
\hline B. rionicus & $5(10)$ & 447 & 6 & $0.844 \pm 0.103$ & $\begin{array}{l}0.00423 \pm \\
0.00102\end{array}$ & 5 & 1.89 & 0 \\
\hline B. tauricus & $2(4)$ & 447 & 1 & 0.0 & 0.0 & 0 & 0.0 & 0 \\
\hline
\end{tabular}

*- including indels 